\title{
ARCHAEOLOGY OF THE 16TH-20TH CENTURY IN THE CZECH REPUBLIC
}

\author{
RUDOLF KRAJÍC - ZDENĚK MĚŘÍNSKÝ - PAVEL VAŘEKA
}

\begin{abstract}
This study is an overview of over fifty years of professional interest in archaeology of the modern age in the Czech lands. It highlights theoretical background and methods that it shares with archaeology focused on medieval periods, as well as new approaches and topics opened by archaeology of the modern era. Despite the fact that in recent decades research mainly focused on the early modern age (16th-18th centuries), reflections upon further development of this sub-discipline necessarily involve the extending of archaeological interest to material remains dating from the modern age and the recent past (19th-20th centuries).
\end{abstract}

Key words: post-medieval archaeology - contemporary archaeology-Czech Republic.

\section{Archeologie novověku v České republice}

Abstrakt: Studie podává přehled o více než půl století trvajícím profesionálním zájmu o archeologii novověkého období na našem území. Poukazuje na společná teoretická východiska a metody s archeologii zkoumajici středověké období, ale i na nové přistupy a témata, které archeologie novovékého obdobi otevirá. Přestože byla v posledních desetiletich pozornost zaměrena převážně na raný novověk (16.-18. století), je nedilnou součástí úvah o dalším vývoji subdiscipliny také rozšiřováni archeologického zájmu o materiální památky z moderní doby a nedávné minulosti (19.-20. století).

Kličová slova: archeologie novověku - archeologie současnosti-Česká republika.

\section{Introduction}

Archaeology of the early modern (16th-18th century), modern and contemporary period (19th-20th century) represents one of the field's most dynamically developing sub-disciplines (chronological definition of the post-medieval, modern and contemporary archaeology see Smetánka-Žegklitz 1990, 7; Vařeka 2013, 8-9). In Bohemia and Moravia, research interest in early modern sites and artefacts has a long tradition and, in recent years, archaeology of the modern and contemporary world has developed intensively. However, attempts to establish a platform with a specialized and periodical series of conferences or a research center/centers have not yet been successful. This paper summarizes the developments and current state of 16th-20th century archaeological research in the Czech Republic and explores its topics, trends and future perspectives.

\section{Emerging interest in early modern archaeological artefacts}

As is the general case in archaeology, initial interest in early modern material culture in Bohemia and Moravia is linked to the establishment of museum collections, in this case in the late 19th - early 20 th century. In addition to the random collection of artefacts evaluated according to art history criteria, archaeological finds were also acquired; the documentation of their contexts, however, was not given much attention. Unique collections of post-medieval finds, mostly pottery, were obtained in Prague. Jan Koula, Professor of the Czech Technical University in Prague, rescued numerous ceramic sets during Prague's historical centre reconstruction at the turn of the 19th/20th century. His publications Co nám vyprávěji pražské střepy (What do Prague sherds tell us) are among the first studies on post-medieval pottery based on archaeological finds in Europe (Koula 1917; 1918; 1919). Similarly, a collection of post-medieval artefacts in the Prague Castle was introduced during reconstruction works by architect K. Fiala in the same period and was later systematically extended to include find complexes, mostly from rescue excavations of cesspits by I. Borkovský, K. Guth and J. Pasternak (Blažková-Vepřeková 2015, 15). K. Čermák holds an exceptional place among Czech museum archaeologists. Čermák is the 
founder of the archaeological collection in Čáslav's museum and he intentionally gained postmedieval artefacts through systematic excavations (Čermák 1896; 1906; 1914; 1914a).

Although in Bohemia a strong influence of art history can be seen in early modern material culture studies, a focus on folk culture, especially traditional pottery, dominated in Moravia. Ceramist and ceramologist H. Landsfeld, who worked in Southern Moravia and South-Western Slovakia, rarely interconnected the ethnographic and archaeological approach in his time. From 1932 on, he carried out several excavations concentrated on early modern Anabaptist production centres (later also other traditional pottery workshops), which focused on revealing the roots of hand-made folk ceramics (Landsfeld 1947; 1950; 1953; 1971). Moravian traditional pottery research, including Anabaptist faience, was also developed by art historian and ceramologist K. Černohorský (1928; 1928a; 1931; 1941).

Sites linked to the Thirty Years' War began to draw attention in the early 20th century. Archivist J. Renner documented field fortifications connected with the battle of Rakovník in 1620 (Renner 1912; 1935); similarly, the Swedish field camp near Mladá Boleslav was studied (Zuman 1931) and the first physical-anthropological investigations regarding Albrecht of Wallenstein's skeletal remains were carried out in the 1920s-1930s (Matiegka-Malý-Bergl 1934; Šimák 1922).

\section{Post-medieval archaeology in 1950s-1980s}

Medieval archaeology began to develop intensively in the 1950s-1960s and extended the chronological framework that was limited to the early medieval or "Slavic period" to the high and late Middle Ages. A lecture by the director of the National Museum in Prague and art historian V. Denkstein in 1953 is considered to be a significant step in the establishment of historical archaeology, as he defined the present as the uppermost limit of this discipline (Denkstein 1953, 200-221; Smetánka-Žegklitz 1990, 10). It should be noted, however, that this timeless vision, which extended to today's contemporary archaeology, was not properly understood at the time. For a long period of time (until the 1980s), records from the early modern and modern period were in most cases perceived as a sort of "secondary product" of archaeological excavations, which, with only few exceptions, had not been properly documented and processed.

In the period when research of later medieval sites was only beginning to develop, systematic excavations of the moated site in Kralice nad Oslavou in Moravia were carried out in 1956-1971 and revealed material remains of the residence of the Bohemian Brethrn's community and their print-workshop, which was in operation in the last quarter of the 16th and first quarter of the 17th century. The Unity of the Brethren, a Czech Protestant Church denomination, printed the so-called "Kralice Bible" here, which was the first complete translation of the Bible from original Biblical languages into Czech. The research was led by V. Fialová, who belonged to the founding generation of medieval archaeologists and was also one of the pioneers of post-medieval archaeology in former Czechoslovakia (Fialová 1956; 1957; 1958). One of the first processed and published sets of early modern ceramics and glass also came from Moravia as a result of rescue-archaeology research of the waste pit in Brno - Orlí Street carried out by B. Novotný in 1957 (Novotný 1959). This set of artefacts, which "shows a colourful image of ceramic and glass production" ("ukazuje na pestrý obraz keramické a sklářské výroby") is dated "to the time when the Habsburgs seized power in the country" ("do doby, kdy se vemi uchopili moci Habsburkové") and was considered to be the material source "for the study of the earliest history of Moravia” ("ke studiu nejstaršich dějin Moravy”; Novotný 1959, 3, 19, 23). Soon after Novotný's research in Brno, B. Nechvátal performed the first rescue excavations in a contemporary village in 1960, which gained recognition for the material culture study of the early modern rural milieu (Nechvátal 1966). In addition to pottery collection, the burnt debris of a farm dated to the 16th century in Struhy (distr. of Mladá Boleslav)) in Bohemia also produced charcoal botanical macroremains analysed by Z. Tempír (ibid, 206). This represented the first attempt at an environmental archaeology approach. Further published sets of post-medieval finds in the same 
period are connected with smaller-scale rescue excavations in the historical centre of Prague (Frauenterka 1958; Liška 1958; Mašek 1966). In the 1960s, Early modern pottery and stove tile studies based on archaeological methods were developed and mostly focused on the typological classification and chronology of these most numerous set of findings (Nechvátal 1968; Smetánka 1968; 1969).

Advancement in post-medieval archaeology in the 1970s and 1980s were mostly linked to the rising number of rescue archaeology excavations, which also naturally uncovered early modern contexts. In regard to building activities, the greatest attention was paid to the historical centres of Bohemian and Moravian towns, including smaller interventions into historical stratigraphy, cesspits and well investigation, but also large-scale excavations of whole house plots (combined in only a few cases with building-archaeology research) and the documentation of public areas such as streets and squares, various urban facilities and fortifications (e.g. Frýda 1979; Bláha 1983; Drda 1980; Himmelová-Procházka 1990; Huml 1971; 1975; 1979; 1989; Charvátová-Charvát 1981; Klápště-Muk 1988; Měřínský 1979; Michna 1977; Richterová 1985; 1986; Šebela-Vaněk 1985; Velímský 1976). The first analysis focused on anthropological material from urban cemeteries (e.g. Fetter 1970; Hanáková-Martinec-Vyhnánek 1975; HanákováStloukal 1988; Stránská 1981) and also on the skeletal remains of famous historical persons (e.g. Albrecht of Wallenstein - Vlček 1976).

Archaeological excavations of early modern field situations in the Prague Castle were henceforward of great importance, and some results of these excavations were published at the time (Boháčová-Frolík-Petř́čcová-Žegklitz 1990; Boháčová-Frolík-Tomková-Žegklitz 1988; Boháčová-Frolík-Žegklitz 1989; Borkovský 1975). Field research of medieval castles and moated sites, as well as monasteries with continual historic development until the early modern period, also recorded their latest phases; however, retrieved data were usually not processed.

Rescue excavations in villages were carried out in much fewer number (Burian 1975; Huml 1982; Kundera-Měŕínský 1987). The Libice project focused on an early medieval hillfort, a part of which was superimposed with the later village. Therefore, interventions also revealed the remains of post-medieval farms and manors (Justová 1981; 1985; Justová 2002). The first archaeological research of a deserted early modern village led by Z. Smetánka and J. Richterová was focused on Německá Lhota (distr. of Kladno), which was abandoned during the Thirty Years' War. This pioneering project compared the testimonies of both documentary and archaeological evidence and pointed out the importance of such investigations for the study of early modern rural sites (Richterová 1981; 1982). As a part of intensive deserted medieval village research activities of that period, several post-medieval rural sites abandoned in the 16th - early 17th century were also documented (e.g. Fröhlich 1986; 1990; Snášil 1982; Vařeka 1989). In the same period, the first early modern village cemeteries' excavations were processed, although the projects targeted on different topics (Budeč - Šolle 1990; Váňa 1995; Oškobrh - Blajerová 1974; Hrdlička-Richter 1974). The study of a deserted modern settlement in the Krkonoše Mountains (Riesengebirge) was a unique project at that period in a wider European context (Bartoš 1976; Kalferst-Sigl 1990; Lokvenc-Bartoš-Švec 1973).

Identification of the earliest preserved rural architecture dated to the turn of the 15 th/16th century - early 17 th century in the 1970 s-1980s was of great importance (Škabrada 1977; 1986; 1987; Škabrada-Dostál 1984; 1985; Škabrada-Smetánka 1974; Škabrada-Syrová 1989; Vařeka 1973). Both corner-timbered (log) and stone-built houses and other parts of farms provided unique comparative material for archaeology but also significantly extended knowledge of the early modern village, especially in cooperation with historical ethnography (e.g. Frolec 1980; Petráňová-Vařeka 1987; Vařeka-Petráňová-Plessingerová 1986; 1988).

A long-term research programme of Czech historical glassworks was established in the 1970s-1980s (Fröhlich 1989; Hejdová 1981; Kavan 1982; Rožmberský 1990), but other production activities were also studied using archaeological methods (see the proceedings of Archeologia technica edited by J. Merta). In Jáchymov (Joachimsthall), for instance, archaeological and 
building-archaeological research revealed the remains of an early 16th century mint including its original equipment (Muk-Hus 1985).

In the 1980s, a new subfield of conflict archaeology appeared, which focused on 17th18th century field fortifications and provided testimonies of military campaigns that frequently affected the Lands of the Bohemian Crown in this period (Matoušek-Hájek-Kubů-Meduna 1990; Hájek-Kubů-Matoušek 1992; Kubů-Zavřel 1988; Meduna 1990). The famous White Mountain battlefield in Prague (1620) yielded several accidental finds of the mass graves of soldiers that were first documented in the 1960s and 1970s (Havel 1980; Janská 1966).

Field research activities provided an increasing quantity of early modern artefacts that in some cases became the subject of targeted processing. Special attention was naturally paid to the most numerous sets of kitchen and table ceramics (e.g. Budinská 1976; Frolík-Sigl 1990; Charvátová-Charvát 1981; Kundera-Měřínský 1987; Matoušek-Scheufler 1980; MatoušekScheufler 1983; Matoušek-Scheufler-Štajnochr 1985), including the whole process of pottery production (Žegklitz 1985; 1990; 1990a). Studies of stove tiles (e.g. Boháčová 1990; Hazlbauer 1988; 1990; Hazlbauer-Špaček 1986; Špaček 1985; Tomková-Hazlbauer 1990; Žegklitz 1987) and other material culture items (e.g. Beranová 1989; Durdík 1990) also gradually developed. The first examples of progressive interdisciplinary ceramic research based on geochemical and petrographic methods can be seen in the late 1980s (Žegklitz-Zavřel 1990).

In Moravia, research interest concerning prominent Anabaptist faience was built upon traditions established in the early 20th century. Ethnographer and archaeologist J. Pajer carried out excavations of several localities and analysed sets of Anabaptist faience and other ceramic ware since 1970s (Pajer 1974, 169-184; 1982; 1983; 1990). In addition to pottery classification, typology, chronology and its functional interpretation, he also dealt with the theoretical issues of historical archaeology and discussed its terminology (Pajer 1983, 7-9), especially the use of a term industrial archaeology which was asserted by J. Merta and a group of researches around him (Merta 1980, 5-8).

In 1982, the Working group for 16th-19th century archaeology (Pracovni skupina pro archeologii 16.-19. stoleti) was established in Brno within the framework of the Czechoslovak Archaeological Society (Československá společnost archeologická). It focused on the terminology, classification and chronology of sites and artefacts according to the regional and thematic specialization of its members (Pajer 1983, 154, footnote 15). The first seminar for post-medieval archaeology was organized in the Beroun Museum in 1986 and represented an important step towards the establishment of this sub-discipline. Papers were published in the seminar proceedings of Studies in Post-Medieval Archaeology 1, which were edited by Z. Smetánka and J. Žegklitz and issued by the Institute of Archaeology Czechoslovak Academy of Sciences in Prague in 1990 (Studies 1990). The editors' introduction to this volume coined the term post-medieval archaeology (postmedieválni archeologie) for this sub-discipline dealing with the 16th-18th century. It summarized its history in Czechoslovakia and its topics, problems and perspectives in an international context and in many ways became its "programme statement" (Smetánka-Žegklitz 1990, 7-21). The foundations for the further development of the Czech post-medieval archaeology were laid out, its aims were outlined and a chronological framework defined. The concept of this archaeological specialization correlated with the study of material culture within the framework of historical sciences using a wide range of sources that were surmounted in a four-volume synthesis of the history of medieval and early modern material culture edited by J. Petráň, which was published in the 1980s and 1990s (Petrán̆ 1985; 1995; 1997; see also Krajíc 2007, 138). ${ }^{1}$

1 The formation of post-medieval archaeology in the Czech lands shares many features in common with developments in this field in other Central European countries (Courtney 2009; Mehler 2013). However, post-medieval archaeology was established and began to develop in Great Britain much earlier. Society for Post-Medieval Archaeology (http://www.spma.org.uk/) has been publishing Post-Medieval Archaeology journal since 1966 (http://www.tandfonline.com/loi/ypma20). An overview of the British post-medieval archaeology before 1990 see e. g. Crossley 1990. 


\section{Post-medieval archaeology developments since 1990}

By looking at the period beginning with the publication of the first post-medieval archaeology proceedings in 1990 (Studies 1990), we can see continuity in the main research directions launched in the period prior to it. We also see the extension and deepening of some previously studied topics and the introduction of new themes as well. The extent of archaeological sources from the post-medieval period has increased considerably in the last 27 years, and the quality of these sources has also significantly improved due to developments in field research methods, artefact and ecofact analysis, and ever-expanding interdisciplinary cooperation. ${ }^{2}$

The vast social and economic transformation of the 1990s in Czechoslovakia/Czech Republic caused intensive building activities. Construction works in the historical centres of both towns and villages and their peripheries, including the reconstruction of historic houses or the construction of new buildings, engineering networks and other infrastructure and the establishment of whole new residential areas, shopping centre complexes and industrial zones irreversibly transformed the appearance of urbanscapes and landscapes in the country. This development required not only an increased need for archaeological field activities, but also changes in archaeological heritage structure and the introduction of new methods in terms of its operation. Not only has the network of specialist workplaces occupied by archaeologists become more concentrated but new institutions have also been set up to dominate the field of archaeological heritage. The extraordinary increase in field research has naturally been reflected in the growing number of investigated modern archaeological records, which on one hand allowed for the broadening knowledge of this period based on archaeological evidence but increased demands on archaeological institutions that had not previously dealt with this period on the other. Thus, post-medieval archaeology has become an integral part of the field research of endangered localities while interdisciplinary cooperation has also intensified.

An attempt to continue on with the post-medieval archaeology seminar was initiated by B. Dragoun and took place in the Opočno Museum in 1999. The organization of regular meetings of scholars interested in post-medieval archaeology was succeeded by the archaeological unit Archaia Praha in the years 2006-2014, when Forum Archaeologiae Post-mediaevalis conferences were held at two-year intervals and soon gained an international dimension. Published proceedings from three of these conferences were edited by J. Žegklitz (Studies 2007; 2009; 2012).

Since the 1990s, papers focusing on post-medieval archaeology have found their place more and more often in central archaeological periodicals and regional journals. There is naturally a research overlap between late medieval and post-medieval archaeology; therefore, studies primarily focused on late medieval archaeology often include a chronologically sequential period but also reflect the historical development of most localities and the interconnection of research topics. Also, archaeology journals and proceedings concentrated on medieval archaeology often include contributions concerning the later period (Archaeologia historica, Castellologica bohemica, Castrum Pragense, Forum urbes medii aevi and Mediaevalia archeologica).

Archaeological and building-history research has become increasingly interconnected, which makes it possible to combine and coordinate new approaches to the rescue and protection of this important component of historical heritage. The expression of such cooperation can be seen in conferences commenced in 2002 and organized by the Association for Historical Building Survey (Sdružení pro stavebně historický prüzkum; proceedings Svorník) and the Conference on Building History (konference Dëjiny staveb), first organized in 2000 by the August Sedláček' Club (Klub Augusta Sedláčka) and later by the Architectural Heritage Center of the National Technical Museum in Plasy (proceedings Dějiny staveb).

As in other chronological specializations, archaeological studies of the post-medieval period are developing in close cooperation with many other disciplines that involve non-destructive

2 Field methods see e.g. Gojda 1997; Gojda-John a kol. 2013; Kuna a kol. 2004; Kuna-Vařeka 2007; Procházka-Vařeka 2005. Coference series "Počitačová podpora v archeologii" is focused on computing in archaeology in the Czech Republic. Interdisciplinary cooperation with natural sciences see journal IANSA (www.iansa.eu.). 
and destructive field research, the assessment of field data, analyses of both artefacts and ecofacts and overall synthesis and interpretation. Apart from traditional cooperation with the historical sciences, contributions from the natural and technical sciences have been increasing. At the beginning of this century, archaeologists met regularly with experts from other disciplines at Natural Science Methods in Archaeology and Anthropology conferences (Prírodovédné metody $v$ archeologii a antropologii), where cooperation developed between archaeologists, natural scientists, physicians, technicians, technologists and other scientists. Volumes of the conference proceedings' Ve službách archaeologie provide an overview of research directions and also include post-medieval archaeology topics.

An important subject of post-medieval archaeology is the research of production facilities and the study of historical technologies. J. Merta from the Technical Museum in Brno has established a long tradition of annual seminars entitled Investigation of Production Facilities and Technologies through Archaeological Methods (Zkoumání výrobnich objektů a technologii archeologickými metodami), the publication of which is represented by a series of proceedings titled Archeologia technica. Concerning modern sites, attention has been paid to the research of e.g. baking ovens, limestone kilns, brick kilns, glassworks or iron production and processing works. The results of the analyses of raw materials, finished products from iron, non-ferrous and precious metals, semi-products, waste, etc. have been also presented.

From the research topics studied after 1989, we will summarize those we consider to be the most important. Significant progress has taken place in the research of the early modern village. Several papers have focused on the state of research, the possibilities of archaeological study of the post-medieval village and traditional architecture (Vařeka 1992; 2007; 2008). Comparative research based on different types of sources has shown possibilities for the assessment of cultural landscape development, settlement structure, field systems (Klír-Beránek 2012; Dohnal 2003; 2003a; 2008; Klír 2008) and ground demarcations (Bayer-Beneš 2004; Beneš-HrubýMichálek-Parkman 1999; Dohnal-Š́da 2007). The programme of the archaeological study of existing villages of medieval origin responded to the growing need for rescue archaeology in cores of historic rural settlements and recognition of acquired data potential (Nováček-Vařeka 1996; 1997). Several published case-studies have shown that archaeology provides irreplaceable evidence for understanding post-medieval village's development, both in the scale of the settlements on a whole and on the micro level of individual farms and their built environment (Dohnal-Vařeka 1997; Dohnal-Korený-Koucký-Procházka-Šamata 2001; Gabriel 1994; Meduna-Kypta-Šulc-Matějek 2001; Militký-Vařeka 1997; Nováček 1997; Nováček-Vařeka 1994; Vařeka-Kostrouch-Kočár-Sůvová 2010). The number of identified earliest preserved village buildings has increased significantly, especially in terms of stone-built architecture and the dendrochronological dating of standing archaic corner-timbered houses, which proved the presence of this architecture in the end of the medieval period (Anderle-Ježek-Zavřel 2000; Berková 1999; Foud-Karel 1998; Kováŕ-Kypta-Šulc 2014; Kypta-Pešta-Šulc-Veselý 2008; Kypta-Šulc 2003; 2004; 2005; 2007; Kypta-Šulc-Veselý 2005; Krásný-Kypta-Šulc 2005; Syrová-Syrový 1992; Škabrada 2003; Šnejd-Hansová 2008). Research of deserted villages' became increasingly focused on post-medieval sites, especially villages abandoned during the Thirty Years' War (Symonds-Vařeka 2016; Vařeka 2009; 2010; 2014; 2015) and investigation of other sites were also carried out as e. g. sheepfolds (Čapek-Preusz 2012) or mills (Beránek-Doležal-Korený-Křivánek-Vařeka 1998; Galusová 2007; Galusová-Funk 2011). Research of the Krkonoše Mountains (Riesengebirge) regarding the late 17th - 19th century settlement was also further developed (Hartmanová 2005). Modern deserted villages abandoned after 1945 in Sudetenland became a new research topic especially in West and South Bohemia (e. g. Bureš 2015; Funk 2010; Galusová 2007; 2010; Matoušek-Holý 2007; Sadravetzová 2011; Vařeka-Balý-Funk-Galusová 2008).

Due to the concentration of construction works, the largest amount of rescue research activities was carried out in towns. So far only a small portion has been processed and published. Studied topics include the development of house plots and burgher houses, production facilities, 
water sources or fortifications (e.g. Beneš 1996; Bláha 1998; Černoš-Hejhal 2012; Dohnal 2006; Ernée 2001; Juřina-Kašák-Samojská 2007; Juřina a kol. 2005; Krajíc 1998; 2006; 2009; Merta-Peška 2009; Motyková-Sedláčková 1996; Motyková-Šenberger 2000; Orna-Dudková 2016; Richterová 1997; Sedláčková 1998; Široký 2000; Vařeka 2004; Vyšohlíd 2015). Some rescue excavations also targeted modern urban cemeteries (e.g. Čiháčková-Omelka- ̌̌ebounová 2011; Kostka-Šmolíková 1998; Loskotová 1999; Omelka-Čebounová-Čechura 2013; Omelka-Řebounová-Šlancarová 2009; Unger 2000) as well as burial areas in the Prague Castle (Blažková-Dubská 2005; 2005a; Tomková 2005). Rescue excavations of monastic and orderly institutions and their cemeteries were presented in few cases (Flek-Kubálek-Omelka-Podliska 2009; Frolík 2007; 2013; 2014; Juřina-Vyšohlíd 2009) as well as Jewish religious sites (FrolíkPecinovská-Vepřeková 2015; Kalferst 1994). A small amount of attention was paid to the processing of aristocratic residence rescue excavations, the research of which remains the domain of architecture and art history (e.g. Foster 2009; Hůrková et al. 2015). Several projects focused on the material remains of execution sites' and gallows' (Fröhlich 2006; Kováŕ 2009; LikovskýVelemínský 2006; Mašková-Michálek 2006; Michálek 2006; Sokol 2003; 2006; 2011; 2016).

Conflict archaeology dealing with early modern battlefields and the remains of sieges has significantly developed using archaeological evidence as well as historical maps and depictions (comprehensive studies see Blažková-Matoušek 2010; Grabolle-Matoušek-Meduna-Smrž 2009; Matoušek 2011a; 2012; 2015a; Matoušek-Blažková 2012; individual sites see Altová-Kössl-Matoušek-Procházka-Šimek 2008; Beneš-Kubů-Török 1995; Blažková 2011; Fröhlich 2000; Kovárník-Horáčková-Vargová-Mucha-Vachunková 2006; Loskotová-Hanák 1995/1996; Matoušek 2006; Matoušek-Kovandová 2005; Smrž-Hluštík 2007; Smrž-MedunaBrůna-Křivánek 1999; Vitula 1997; Walhauser 2009). The intensive study of glassworks' followed the earlier research tradition (Fröhlich 1993; 1994; 1994a; 1995; 1995a; 1996; 2015; Frýda 2014; Hrubý-Hejhal-Kašák-Malý-Valkony 2009; Stará 2007; Žegklitz 2007; Žegklitz-Hazlbauer-Chotěbor 1992; see also proceedings Historické sklo) and was accompanied by other sites connected with production activities outside towns (e.g. Bláha-Sigl 2007; Dragoun-Matoušek 2004; Dragoun-Matoušek-Woitsch 2006; Kováŕ 2014; see also proceedings Archeologia technica). Promising progress has recently been made in the field of mining archaeology, which has been using new methods of remote sensing, especially aerial scanning and other advanced field techniques (e.g. Malina 2014; 2015; 2016; Malina-Karel 2012; Malina-Urban 2013; see also proceedings Střibrná Jihlava and the international project ArchaeoMontan in Krušné hory/ Erzgebirge; http://www.archaeomontan.eu/archaeomontan.html). Archaeological methods have also brought new evidence regarding old roads (e.g. Hlásek-Gersdorfová-Hrušková-PlzákPták-Stehlíková 2014; Kubů-Zavřel 2007; Zavřel 1999) and the earliest railway system (horse drawn track - Hajn-Chvojka-Majer 2004; Chvojka-Menšík 2013). A new specialization has recently appeared in the study of material remains of hunting and remains of parks, game-reserves (Preusz-Paclíková-Pták 2013; Tůma 2008; 2010; 2012; Tůma-Zelinková 2011) and gardens (Gojda-Hladký-Janál-Jančo-Milo-Lisá-Petř́k-Prokeš 2015).

Regarding movable artefacts, pottery represents the most frequently analysed item of material culture. Recent studies have brought new insights into technology, morphology and decoration techniques and have broadened our knowledge of chronology. They also began to define individual wares and their provenience (e.g. Blažková 2013; Blažková-Dubská 2007; 2009; Blažková-Frolík-Žegklitzová 2012; Cvrková 2001; Čapek-Preusz 2016; Dohnal-Fröhlich 2000; Dohnal-Vařeka 2002; Chybová-Válka 1994; Malík-Peška 1994; Preusz 2013; Vařeka 2003). Special attention was paid to fine ware such as faience, majolica and mezzomajolica (Pajer 1996; 2001; 2001a; 2007; Štajnochr 1990; 1998; Štajnochr-Fröhlich-Krajíc-Militký 1998; Vyšohlíd 2014a) as well as to traditional pottery which is of a great importance for archaeological data interpretation (Štajnochr 2004; 2005; 2006; 2007; 2008). Literature about late Gothic and Renaissance stove tiles has grown extraordinarily. It includes catalogues (Brych 2004; BrychStehlíková-Žegklitz 1990; Fröhlich-Pavlík 2014; 2015; Krasnokutská 2005; MenouškováMěřínský 2008; Orna 2005; Pavlík-Vitanovský 2004), find complex’ analyses from rural sites 
(Dreslerová-Kypta-Šulc 2004; Fröhlich-Kypta 2010; Korený-Kypta-Šulc 2003; Kypta-Šulc 2006; Šulc-Kypta-Ježek 2009), towns (Drobný-Sedláčková 1997; Čapek 2016; Holub-Jordánková-Loskotová 2009; Kováčik-Veselá 2009), royal and aristocratic residences (Brych 2001; Durdík-Hazlbauer 1991; Durdík-Pavlík 2016; Durdík-Juřina-Pavlík 2010; Ernée 2004; Hazlbauer 1997; Hazlbauer-Hlaváček 1997; Hazlbauer-Waldhauser 1998; Tetour 2005), and studies on typology, motifs and iconography, as well as the chronology and reconstruction of stoves (Hazlbauer 1998; 2000; Hazlbauer-Durdík 1996; Hazlbauer-Glosová-Volf 1996; Loskotová 2012; Motyková-Hazlbauer 1999; Pavlík-Vitanovský 2008; Soukup-Soukupová-Šrejbr 2012; Tymonová 2007; 2012; Vitanovský-Menoušková 2010; Žegklitz 2006; 2011; 2012; 2014; ŽegklitzVitanovský-Zavřel 2009; Žegklitz-Zavřel 2004). Most recently, the importance of studying clay tobacco-pipes in the archaeological context has been recognized (Musil 2008; Preusz 2015; 2016; Ulrychová 2010; Vyšohlíd 2007; 2009; 2011; 2014). As for other types of artefacts, analyses of glass (Černá 2002; Drahotová-Žegklitzová-Veselá 2003; Drobný-Sedláčková 1997; Jordánková-Sedláčková 2004; Krajíc 2003; Krajíc-Podliska-Sedláčková-Veselá 2005; Sedláčková 2000; 2001; 2001a; 2007; Sedláčková-Rohanová 2016; see proceedings Historické sklo), textiles, footwear (Bravermanová 1998; Bravermanová-Březinová-Hlaváček 1998; Bravermanová-Čierna 1997; Bravermanová-Kobrlová-Samohýlová 1994; 1995; Pilná-Schmollová 2014) and militaries can be mentioned (Beneš-Kubů-Török 1995; Chmielowiec-Kašpar-Zdaniewicz 2013; Musil 2010; 2015). Considerable attention has been focused on jewelry in recent years, especially to small personal accessory items and devotionalia that were revealed during excavations of post-medieval cemeteries (Čiháčková-Omelka-Řebounová 2011; Loskotová 1999; Měchurová

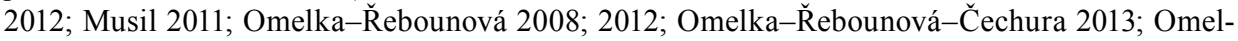
ka-Ǩebounová-Šlancarová 2009; 2010; Omelka-Šlancarová 2007; Thomová 2004; 2005).

Studies regarding the natural environment of the early modern period have been greatly expanded, as archaeo-biological analyses have already become a regular part of post-medieval site' field research. A growing number of studies deals with botanical macroremains (BenešKočár 2000; Bouda-Kočár 2011; Kočár-Jankovská-Starec-Huml 2007; Kočár-KočárováSůvová-Petr 2009; Kočár-Sůvová-Kočárová-Kyncl 2007; Kosňovská-Houfková-Kovář 2011; Opravil 2002; Schnederwinklová-Kostrouch-Sůvová-Kočár-Kočárová-Kyncl-Klozar-Petr 2008), especially evidence of plants, crops and spices (Čulíková 1995; 2007; 2008; 2014; KočárBeneš-Preusz-Vaněček 2015; Preusz-Kodýdková-Kočár-Vaněček 2015), or the analysis of archaeo-zoological finds (e.g. Petříčková 1997; Preusz-Beneš-Kovačiková 2014; Sůvová 2008; Sůvová-Wasková 2009).

\section{The archaeology of modernity}

Archaeology of the 19th-20th century has been developing in the Czech Republic for a small number of years; however, it is necessary to point out that archaeological contexts from this period were at least sampled and documented in previous decades during responsibly led excavations. Contrary to industrial archaeology, the formation of which was much delayed in comparison with Western Europe and overseas, ${ }^{3}$ contemporary archaeology ${ }^{4}$ emerged in the Czech Republic in a small time distance compared to international trends and is in close contact with foreign scholars and academic institutions (e. g. project "Accessing Campscapes: Inclusive Strategies for Using European Conflicted Heritage"; http://www.campscapes.org/). ${ }^{5}$

Archaeological sites from the recent past were registered already in the period when postmedieval archaeology was being established; nevertheless, systematic and targeted research has only been developing since the 2000 s. Several projects focusing on the 19 th - early 20 th century

\footnotetext{
3 Industrial archaeology e. g. Buchanan 1972; Butt-Donnachie 1979; Cassela-Symonds 2005; Palmer-Nevell-Sissons 2012; Palmer-Neaverson 1998 .

4 The term contemporary archaeology (archeologie současnosti) was used in the Czech milieu for the first time by V. Matoušek regarding his research on the earliest archaeological evidence of human activities in caves (Matoušek 1992).

5 Contemporary archaeology e. g. Buchli-Lucas 2001; Graves-Brown 2000; Graves-Brown-Harrison-Piccini 2013 ; Harrison-Schofield 2010. Czech archaeology of the 19th-20th century see Matoušek 2011; 2015; Vařeka 2013.
} 
industrialization of Bohemia were carried out in recent years and mostly included studies on industrial and transport facilities as well as the transformation of urban areas. ${ }^{6}$ Contemporary archaeology in the Czech Republic has explored several topics showing the potential of this new sub-discipline for understanding the recent past based on material remains. ${ }^{7}$ Main research themes include deserted modern villages (see above), contemporary cemeteries (FarkašováHložek-Menšík 2013; Nenutil- Rak-Friedl-Funk-Hložek-Marková-Menšík-Netolický 2011; Vařeka-Vařeková 2016), material testimony of the Second World War and the Cold War (Bureš 2013; Hasil-Novák-Hasil 2015; Nenutil-Rak a kol. 2011; Rak 2014; Rak-Vladař 2010), materiality of the Communist Era (Vařeka-Vařeková 2015), archaeology of resorts, recreation and leisure activities (Blažková-Fialová-Matoušek 2014; Matoušek 2014; 2015b; Matoušek-Koukalová-Šášinková 2014; Symonds-Vařeka 2014; Šimková 2014; Vařeka-Symonds 2013) and garbology (Brunclíková-Sosna 2012; 2014; Sosna-Brunclíková-Henig 2013; Sosna 2016). Contemporary archaeology opens up new perspectives in building theoretical models and can make a significant contribution to the development of archaeological theory (in the Czech academic milieu, see Neustupný 2013). Only one seminar on the archaeology of modernity has been arranged so far and was organized by the Department of Archaeology at the University of West Bohemia in Pilsen in 2011. Its proceedings were published in the volume Archaeology of the 19th and 20th centuries. Approaches - methods - topics (Archeologie 19. a 20. století. Pristupymetody-témata) edited by P. Vařeka (2013). The first international conference on contemporary archaeology was also held in Pilsen and focused on the possibilities of exploring the dark heritage of the recent past (Dark Modernities: Archaeologies of Totalitarianism, Authoritarianism and Repression organised in 2014 as the Annual Contemporary and Historical Archaeology in Theory Conference).

\section{Conclusions}

The overview above shows the gradual establishment of post-medieval archaeology and its rapid development in the last three decades. The outline of studied topics indicates the long-term continuity of some research areas, a search for new directions and a significant trend in developing interdisciplinary cooperation. Post-medieval archaeology in the Czech lands emerged from the archaeology of the Middle Ages, with which it is still closely linked; in addition, ethnology, building history and art history also played a significant role in its formation. At the same time, it was closely connected with rescue archaeology and heritage protection, which opened up a number of possibilities to conduct fieldwork of sites from the modern past that would otherwise have been ignored. On the other hand, however, this fact significantly influenced but also limited post-medieval archaeology to a certain extent. So far, systematic and targeted research activities focusing on carefully chosen sets of questions have been carried out only in a few cases. Post-medieval archaeology has not been greatly involved in discussions of archaeological theory in the Czech academic environment. In addition to quite recently established postmedieval archaeology, a new specialization dealing with the 19th-20th centuries has already emerged in recent years, showing that archaeological evidence provides irreplaceable data for the study of the recent past. Archaeology represents the only discipline that builds a theoretical background and the methodological tools for the complex research of artefacts, regardless of their age. Due to the archaeology of modernity, the traditionally assumed long-term distance between the subject of archaeological exploration and the present is gradually disappearing. We

6 Research programme led by V. Matoušek is carried out by the Centre for complex study of material and landscape aspects of the industrialization process (Centrum pro komplexni studium materiálnich a krajinotvorných aspektů industrializačního procesu) at the Faculty of Humanities Charles University in Prague (Blažková-Matoušek 2013; 2013a; see also Blažková-Fialová-Matoušek 2014; Matoušek 2010; Matoušek-Blažková 2015)

7 The research activities regarding contemporary archaeology are concentrated significantly at the Department of Archaeology University of West Bohemia in Pilsen, where several projects have been carried out, ca. 40 student theses focusing on the 19th-20th century topics were defended (see Vařeka 2013) and a module of "Archaeology of Modernity" study specialisation has been included in the Masters' programme. In recent years, 19th-20th century archaeology has been developing also in other institutions, esp. in the Institute of Archaeology University of South Bohemia in České Budějovice. 
believe that the archaeology of the 16th to 20th centuries in the Czech Republic should have its own discussion and conference platform of regular research meetings within a Central European context at the least. The significance of post-medieval and contemporary archaeology among historical sciences was well demonstarted at the Archaeologia historica conference in České Budějovice in 2016.

Part of the study was supported by the project GA ČR, nr. GA15-03380S - A Land Transformed: An Interdisciplinary Investigation into the Impact of the Thirty Years' War on the Rural Landscape of Bohemia.

Translation Pavel Vařeka, proofreading Skyland Václav Kobylak.

\section{Literature}

ALTOVÁ, B.-KÖSSL, A.-MATOUŠEK, V.-PROCHÁZKA, Z.-ŠIMEK, J., 2008: Tzv. Tillyho šance u Rozvadova ve světle terénní dokumentace a ikonografických pramenů, předběžná zpráva - Die sogenannten Tilly-Schanzen bei Rosshaupt (Rozvadov) im Licht der Terraindokumentation sowie der ikonographischen und kartographischen Quellen, Landkreis Tachau (Tachov), Westböhmen. In: Archeologické výzkumy v severozápadních Čechách v letech 2003-2007. Sborník k životnímu jubileu Zdeňka Smrže (Černá, E.-Kuljavceva-Hlavová, J., edd.), 359-374. Most.

ANDERLE, J.-JEŽEK, M.-ZAVŘEL, P., 2000: Průzkum selské usedlosti čp. 2 v Sakách na Slánsku - Durchforschungsergebnisse vom Bauernsitz Konskr.-Nr. 2 in Saky, PRP 7, č. 1, $43-67$.

BARTOŠ, M., 1976: Nález kachlů z poloviny 18. století na Labské louce v Krkonoších, Český lid LXIII, $231-235$.

BAYER, T.-BENEŠ, J., 2004: Středověká terasová pole na Šumavě jako hydropedologický fenomén a archeologický problém - Medieval terraced fields in the Bohemian Forest as a hydropedological phenomenon and problem of landscape archaeology, AR LVI, 139-159.

BENEŠ, J., 1996: Archeologický a archeobotanický výzkum pozdně středověkého vodovodního díla $\mathrm{z}$ Prachatic, Zlatá stezka. Sborník Prachatického muzea 3, 158-181.

BENEŠ, J.-HRUBÝ, P.-MICHÁLEK, J.-PARKMAN, M., 1999: Kamenná ohrazení na Hořejším vrchu a vrchu Kokovci u Vlachova Březí. Př́íspěvek ke studiu agrární krajiny šumavského podhůří, Zlatá stezka. Sborník Prachatického muzea 6, 273-298.

BENEŠ, J.-KOČÁR, P., 2000: Novověké obilnářství vsi Laziště (okr. Prachatice) v Pošumaví na základě archeobotanické makrozbytkové analýzy. Nahý ječmen Hordeum vulgare convar. distochon var. nudum - středověký relikt nebo novověký výsadek? - Die neuzeitliche Getreidewirtschaft des Dorfs Lažiště (Kreis Prachatice) im Vorböhmerwald auf Grund einer archäobotanischen Makrorestenanalyse: Die Nacktgerste Hordeum vulgare convar. Distichonvar. Nuchen - mittelalterliches Relikt oder neuzeitliche Pflanzung?, AVJČ 13, 185-196.

BENEŠ, J.-KUBŮ, F.-TÖRÖK, J., 1995: Soubor militarií z počátku třicetileté války z Volarských šancí - Die an den Wallerer Schanzen gefundene Militarienkollektion aus dem Anfang des Dreissigjährigen Krieges, AR XLVII, 461-480.

BERÁNEK, J.-DOLEŽAL, D.-KORENÝ, R.-KŘIVÁNEK, R.-VAŘEKA, P., 1998: Větrný mlýn holandského typu v Př́ícovech, Podbrdsko 5, 30-52.

BERANOVÁ, M., 1989: Kovové vínky pražských dívek ze 17. a první poloviny 18. století. Příspěvek k lidovému šperkařství - Metallkränzchen der Mädchen aus Prag aus dem 17. und aus der 1. Hälfte des 18. Jhs. Beitrag zum Volksschmuckwesen, Archaeologica Pragensia 10, 269-280.

BERKOVÁ, J., 1999: Saky, čp. 2 - nález jádra středověkého vesnického domu v obci Saky, PSČ 13/1, 41-45.

BLÁHA, J., 1983: K vypovídacím možnostem olomouckého archeologického materiálu 15. až 17. století, Historická Olomouc a její současné problémy 4, 307-315.

- 1998: Komunikace, topografie a importy ve středověku a raném novověku (7.-17. století) na území města Olomouce - Die Kommunikationen, Topographie und Importe im Mittelalter und in der Frühneuzeit (7.-17. Jh.) auf dem Gebiet der Stadt Olmütz, AH 23, 133-159.

BLÁHA, R.-SIGL, J., 2007: Archaeological excavation of Modern period brickworks on the Kimberly-Clark site in Jaroměř, Studies in Post-Medieval Archaeology 2, 137-144.

BLAJEROVÁ, M., 1974: Antropologická charakteristika kosterních pozůstatků ze středověkého pohřebiště na Oškobrhu - Die anthropologische Charakteristik des Skelettmaterials vom mittelalterlichen Friedhof Oškobrh, PA LXV, 185-217.

BLAŽKOVÁ, G., 2013: Vývoj raně novověké kuchyňské a stolní keramiky v Čechách na základě souborů z Pražského hradu - The development of Early Modern ceramic kitchenware and tableware in Bohemia based on assemblages from Prague Castle, PA CIV, 183-230. 
BLAŽKOVÁ, G.-VEPŘEKOVÁ, J., 2015: Nálezy hmotné kultury z renesančních odpadních jímek z Pražského hradu. Díl I. Katalog. Castrum Pragense 13. Praha.

BLAŽKOVÁ, G.-FROLÍK, J.-ŽEGKLITZOVÁ, J., 2012: Early Modern archaeological assemblages from Prague Castle and period written and iconographic sources, Studies in Post-Medieval Archaeology 4, 189-232.

BLAŽKOVÁ-DUBSKÁ, G., 2005: Archeologický výzkum novověkého pohřebiště u Jízdárny, Castrum Pragense 7, 403-410.

- 2005a: Několik poznámek k archeologickému studiu novověkého pohřbívání v Čechách (Úvod ke studiu novověkých pohřebišt' na Pražském hradě), Castrum Pragense 7, 201-216.

- 2007: House of the armoury scribe at Prague Castle, Studies in Post-Medieval Archaeology 2, 9-42.

- 2009: Finds of Early Modern period ceramics from cesspit B at Prague Castle, Studies in Post-Medieval Archaeology 3, 21-44.

BLAŽKOVÁ, K., ed., 2011: Bitva u Rakovníka 1620. Rakovník.

BLAŽKOVÁ, T.-FIALOVÁ, D.-MATOUŠEK, V., edd., 2014: Individuální a masová rekreace v okolí velkých industriálních měst v 19.- 21. století. Praha.

BLAŽKOVÁ, T.-MATOUŠEK, V., 2010: The Complex Research of the Thirty Year's War Battlefields in the Czech Republic, Śląskie Sprawozdania Archeologiczne 52, 427-436.

- 2013: Česká krajina 19. a 20. století ve světle industriální archeologie - stav bádání. In: Archeologie Modernity. Přístupy - metody - témata (Vařeka, P., ed.), 17-22. Plzeň.

- 2013a: Kvalifikační práce a projekty industriální archeologie na Fakultě humanitních studií Univerzity Karlovy. In: Archeologie Modernity. Př́istupy - metody - témata (Vařeka, P., ed.), 171-174. Plzeň.

BOHÁČOVÁ, I., 1990: Neznámý kachel z Pražského hradu se starozákonním motivem - An unknown stove title from Prague Castle with an Old Testament motiv, Studies in Post-Medieval Archaeology 1, 261-262.

BOHÁČOVÁ, I.-FROLÍK, J.-TOMKOVÁ, K.-ŽEGKLITZ, J., 1988: Předběžné výsledky výzkumu Pražského hradu v letech 1980-1987 - Vorläufige Ergebnisse der Erforschung der Prager Burg in den Jahren 1980-1987, AH 13, 173-198.

BOHÁČOVÁ, I.-FROLÍK, J.-ŽEGKLITZ, J., 1989: Jiřské náměstí na Pražském hradě. Shrnutí výsledků 1. etapy výzkumu - Der Georg-Platz auf der Prager Burg. Ergebnisse der ersten Forschungsetappe, AH 14, 193-202.

BOHÁČOVÁ, I.-FROLÍK, J.-PETŘÍČKOVÁ, J.-ŽEGKLITZ, J., 1990: Příspěvek k poznání života a životního prostředí na Pražském hradě a Hradčanech - Ein Beitrag zur Kenntnis des Lebens und der Umwelt auf der Prager Burg und Hradčany, AH 15, 177-189.

BORKOVSKÝ, I., 1975: Svatojiřská bazilika a klášter na Pražském hradě. Praha.

BOUDA, J.-KOČÁR, P., 2011: Merklín - ulice 1. máje, raně novověké spáleniště studované pomocí metod environmentální archeologie - Merklín - Straße ulice 1. máje, frühneuzeitliche mittels der Methoden der Enviromentalarchäologie untersuchte Brandstätte, AZČ 2, 173-181.

BRAVERMANOVÁ, M., 1998: Textilie. In: Krajíc, R. a kol., Dům pasíře Prokopa v Táboře. Archeologický výzkum odpadní jímky v domě čp. 220, 125-127, 195-197. Tábor.

BRAVERMANOVÁ, M.-BŘEZINOVÁ, H.-HLAVÁČEK, P., 1998: Soubor renesančních bot ze studny u kostela Všech svatých na Pražském hradě - Die Kollektion von Renaissanceschuhen aus dem Brunnen an der allerheiligenkirche in Prager Burg, AH 23, 471-492.

BRAVERMANOVÁ, M.-ČIERNA, A., 1997: Pohřební textilie z hrobu Rudolfa II. v královské hrobce v katedrále sv. Víta na Pražském hradě - Leichentextilien aus dem Grab des Rudolf II. aus der Köningsgruft im St. Veitsdom in der Prager Burg, AH 22, 363-385.

BRAVERMANOVÁ, M.-KOBRLOVÁ, J.-SAMOHÝLOVÁ, A., 1994: Textilie z hrobu Anny Jagellonské z Colinova mauzolea v katedrále sv. Víta na Pražském hradě - Textilien aus der Grabstätte der Anna Jagellone, AH 19, 437-461.

- 1995: Textilie z hrobu Maxmiliána II. Habsburského z Colinova mauzolea v katedrále sv. Víta na Pražském hradě - Textilien aus dem Grab des Maxmilian II. von Habsburg aus dem Colin-Mausoleum im St. Veitsdom in der Prager Burg, AH 20, 497-521.

BRUNCLÍKOVÁ, L.-SOSNA, D., 2012: Garbologie: zrcadlo konzumní společnosti, Antropowebzin 3/2012, 131-139.

- 2014: Cesta do hlubin kontejneru, Antropowebzin 1/2014, 1-9.

BRYCH, V., 2001: Kachle z tvrze Křešic u Divišova. K poznání kamnářské produkce pozdní gotiky a renesance ve středních Čechách - Stove tiles from fortified manor at Křešice u Divišova. On Late Gothic and Renaissance stove-making in Central Bohemia, ASČ 5, 665-688.

- 2004: Kachle doby gotické, renesanční a raně barokní. Výběrový katalog Národního muzea v Praze. Praha.

BRYCH, V.-STEHLÍKOVÁ, D.-ŽEGKLITZ, J., 1990: Pražské kachle doby gotické a renesanční. Katalog výstavy. Praha.

BUDINSKÁ, J., 1976: Přríspěvek k dějinám hrnčiřství v Levíně. Monografické studie Krajského muzea v Teplicích 10. Teplice.

BUCHANAN, R. A., 1972: Industrial Archaeology in Britain. Harmondsworth.

BUCHLI, V.-LUCAS, G., edd., 2001: Archaeologies of Contemporary Past. London - New York. 
BUREŠ, M., 2013: Odraz Železné opony v datech leteckého laserového skenování na př́ikladu Novohradských hor. In: Archeologie a letecké laserové skenování krajiny (Gojda, M.-John, J., edd.), 221-227. Plzeň.

- 2015: Vesnice zaniklé po roce 1945 a kulturní krajina Novohradských hor. Plzeň.

BURIAN, V., 1975: Obilní jáma v Komořanech (okr. Vyškov), PV 1974, 75-78.

BUTT, J.-DONNACHIE, I., 1979: Industrial Archaeology in the British Isles. London.

CASSELA, E. C.-SYMONDS, J., edd., 2005: Industrial Archaeology. Future Directions. New York.

COURTNEY, P., 2009: The Current State and Future prospects of Theory in European Post-Medieval Archaeology. In: International Handbook of Historical Archaeology (Majewski, T.-Gaimster, D., edd.), 169-189. New York.

CROSSLEY, D., 1990: Post-medieval Archaeology in Britain. London - Leicester - New York.

ČAPEK, L., 2016: Kamnářská keramika. In: Historická radnice v Českých Budějovicích ve světle archeologických výzkumů a rozboru hmotných pramenů (Čapek, L.-Militký, J. a kol., edd.), 237-252. Plzeň - České Budějovice.

ČAPEK, L.-PREUSZ, M., 2012: Chov ovcí, ovčíny a sociální struktura ovčího řemesla ve středověku a novověku v Čechách a na Moravě, Kuděj 2, 6-35.

- 2016: Středověká a novověká keramika z nádvoří radnice. In: Historická radnice v Českých Budějovicích ve světle archeologických výzkumů a rozboru hmotných pramenů (Čapek, L.-Militký, J. a kol., edd.), 121-214. Plzeň - České Budějovice.

ČERMÁK, K., 1896: Hrnčíríi v Čáslavi a jejich památky, PA XVII, 214-223.

- 1906: Hrnčířské dílny v Č́slavi v době renaissanční, PA XXI, 567-572.

- 1914: Hrnčířské památky z Čáslavska, Muzejník čáslavský 2, 37-47.

- 1914a: Hrnčířské dílny v Č́slavi, Muzejník čáslavský 2, 47-52.

ČERNÁ, E., 2002: Sklo 13. až 16. století. In: Klápště, J. a kol., Archeologie středověkého domu v Mostě (čp. 226). Mediaevalia archaeologica 4, 93-115. Praha - Most.

ČERNOHORSKÝ, K., 1928: Československá lidová keramika. Příspěvky k soubornému studiu. Národopisný sborník československý 23. Praha.

- 1928a: Př́ispěvky k dějinám moravských fayensí. Opava.

- 1935: Poznámky k fajánsové výrobě v Prostějově. Prostějov.

- 1941: Moravská lidová keramika. Praha.

ČERNOŠ, Š.-HEJHAL, P., 2012: Archaeological excavations of Jihlava's Early Modern fortifications (20032010), Studies in Post-Medieval Archaeology 4, 389-403.

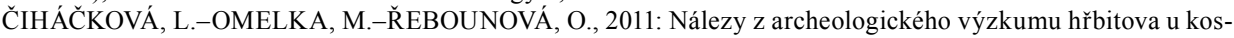
tela sv. Bartoloměje v Rakovníku. Př́spěvek k poznání pohřební výbavy obyvatel barokního města - Finds recovered during the archaeological excavations undertaken at the cemetery at St Bartholomew's Church in Rakovník. A contribution to our knowledge of objects deposited in graves of citizens of a Baroque town, ASČ $15,1029-1049$

ČULÍKOVÁ, V., 1995: Zpráva o prvním archeobotanickém nálezu tabáku (r. Nicotina L.) ve střední Evropě Nachricht über den ersten archäobotanischen Tabakfund (G. Nicotina L.) in Mitteleuropa, AH 20, 615-619.

- 2007: Zpráva o prvním archeobotanickém nálezu líčidla amerického (Phytolacca americana L.) ve střední Evropě a o dalších druzích užitkových rostlin z Prahy-Hradčan - Report about the first archeobotanical find of poke weed (Phytolacca americana L.) in the Middle Europe and other species of utility plants from Prague-Hradčany, AR LIX, 353-370.

- 2008: Ovoce, koření a léčiva z raně novověké jímky hradčanského špitálu - Fruits, spices and medicaments from the post-Medieval cesspit of hospital at Prague-Hradčany, AR LX, 229-260.

- 2014: Moderní sortiment užitkových rostlin v barokové jímce v Thunovské ulici čp. 192 na Malé Straně v Praze, Staletá Praha XXIX, č. 2, 64-119.

DENKSTEIN, V., 1953: O úkolech historické archeologie, ČNM - Oddíl věd společenských 122, $219-223$.

DOHNAL, M., 2003: Historická kulturní krajina v novověku. Vývoj vsi a plužiny v Borovanech u Bechyně. Praha.

- 2003a: Proměny půdorysného uspořádání osad v okolí Milevska v pozdním středověku a novověku - Changes in the layout of villages around Milevsko in the Late Medieval and Early Modern periods, ASČ 7, 795-840.

- 2006: Vybrané archeologické výzkumy v historickém jádru města Berouna v roce 2004 - Selected archaeological excavations from the historic centre of Beroun in 2004, ASČ 10, 927-944.

- 2008: Změny krajiny v pozdním středověku a raném novověku v jižním okolí Čáslavi. Rybniční hospodářství ve Zbýšově a Šebestovicích - Changes in the landscape in the Late Middle Ages and Early Modern Times in the southern vicinity of Čáslav. Fish farming in Zbýšov and Šebestěnice, ASČ 12, 829-848.

DOHNAL, M.-FRÖHLICH, J., 2000: Výzkum parkánu u kasáren v Písku (Vyhodnocení souboru novověké keramiky) - Research of the moat by barracks in Písek (An evaluation of the postmedieval pottery collection), AVJČ $13,155-184$.

DOHNAL, M.-KORENÝ, R.-KOUCKÝ, K.-PROCHÁZKA, L.-ŠAMATA, J., 2001: Obděnice čp. 4 (okr. Př́bram). Dějiny usedlosti ve světle etnografických, archeologických, písemných a paleozoologických 
pramenů - No 4, Obděnice (Př́ibram district). The history of a homestead in the light of ethnographic, archaeological, written and palaeozoological sources, ASČ 5, 721-738.

DOHNAL, M.-ŠÍDA, P., 2007: Historické způsoby značení pozemkových hranic a problematika tzv. mohylovitých útvarů - Historical methods for marking territorial boundaries and the problem of "tumulus" formations, ASČ $11,635-652$.

DOHNAL, M.-VAŘEKA, P., 1997: Výzkum novověké vesnické usedlosti v Srlíně (okr. Písek) - svědectví archeologických a písemných pramenů - Research of the postmedieval farm in Srlín (distr. of Písek) - archaeological and documentary evidence, AVJČ 10, 1997, 84-106.

- 2002: Novověké artefakty z bývalého kapucínského kláštera v areálu někdejších kasáren Jiřího z Poděbrad na náměstí Republiky v Praze 1 (Zjištovací výzkum v letech 1998-1999) - Early modern artefacts from the former Capuchin monastery on nám. Republiky in Prague 1 (test trenching in 1998-1999), Archaeologica Pragensia 16, 251-294.

DRAGOUN, B.-MATOUŠEK, V., 2004: Archeologický odkryv uhliště v Olbramově a experimentální pálení dřevěného uhlí v Uhř́nově. Př́íspěvek k pálení dřevěného uhlí, zvláště v novověku - Die archäologische Untersuchung eines Meilerplatzes in Obramov und das experimentelle Holzkohlbrennen in Uhř́nov. Ein Beitrag zur Problematik der (neuzeitlichen) Holzkohlgewinnung, ASČ 8, 727-772.

DRAHOTOVÁ, O.-ŽEGKLITZOVÁ-VESELÁ, J., 2003: Die Typen der Renaissancekelchglässer (Weingläser) in venezianischer Art aus böhmoischen und mährischen Fundorten, Beiträge zur Mittelalterarchäologie in Österreich 19, 119-126.

DRDA, M., 1980: Archeologický výzkum Tábora - Die archäologische Erforschung der Stadt Tábor, AH 5, $107-113$.

DRESLEROVÁ, D.-KYPTA, J.-ŠULC, J., 2004: Gotické kachle ze zaniklé vsi Újezdec u Borku, ASČ 8, 685-698.

DROBNÝ, T.-SEDLÁČKOVÁ, H., 1997: Kachle a sklo z odpadní jímky ze 16. století v Olomouci, MVP 35, 129-140.

DURDÍK, T., 1990: Fragment prachovnice ze Zbečna - Fragment of a gunpowder horn from Zbečno, Studies in Post-Medieval Archaeology 1, 257-260.

DURDÍK, T.-HAZLBAUER, Z., 1991: Pozdně gotické a renesanční kachle ze severního parkánu horního hradu na Křivoklátě - Spätgotische und Renaissance Kacheln aus dem nördlichen Zwinger der oberen Burg Křivoklát. I. Teil, CB 2, 279-300.

DURDÍK, T.-JUŘINA, P.-PAVLÍK, Č., 2010: Nález zbytků pozdně renesančních kachlových kamen na hradě Buštěhradě, CB 12, 509-528.

DURDÍK, T.-PAVLÍK, Č., 2016: Zbytky novověkých kachlů z tvrze Tiché u Kaplice - Bruchstücke neuzeitlicher Ofenkacheln von der Feste Tichá bei Kaplice, CB 13, 281-289.

ERNÉE, M., 2001: Pícka Sebalda Matighofera. Pohled do dílny rožmberského přepalovače stř́ibra - Der Probierofen von Sebald Matighofer. Einblick in die Werkstätte des Rosenberger Silberbrenners, AH 26, $27-42$.

- 2004: Gotické a renesanční komorové kachle z hradu a zámku v Českém Krumlově - Ofenkacheln der Gotik und Renaissance aus der Burg und dem Schloss in Český Krumlov (Böhmische Krumau), CB 9, 251-268.

FARKAŠOVÁ, K.-HLOŽEK, J.-MENŠÍK, P., 2013: Výzkum bývalého městského hřbitova v Rokycanech. In: Archeologie Modernity. Př́istupy - metody - témata (Vařeka, P., ed.), 99-114. Plzeň.

FETTER, V., 1970: Antropologický průzkum hřbitova ze 17. století v Benešově u Prahy, Sborník vlastivědných prací z Podblanicka 11, 308-314.

FIALOVÁ, V., 1956: Archeologický výzkum tvrze v Kralicích nad Oslavou, VVM XI, Brno, 176-179.

- 1957: Historicko-archeologický výzkum tvrze a kostela v Kralicích nad Oslavou, ČMMZ XLII, 67-84.

- 1958: Historicko-archeologický výzkum tvrze a kostela v Kralicích nad Oslavou, ČMMZ XLIII, 67-80.

FLEK, F.-KUBÁLEK, P.-OMELKA, M.-PODLISKA, J., 2009: Excavation of the Early Modern period cemetery on the grounds of the former Capuchin monastery at St. Jospeh's in Prague's New Town, Studies in Post-Medieval Archaeology 3, 407-452.

FOSTER, L., 2009: The baroque kitchen at Bečov nad Teplou castle, Studies in Post-Medieval Archaeology 3, 65-92.

FOUD, K.-KAREL, T., 1998: Lidová architektura - město Plzeň. Plzeň.

FRAUENTERKA, M., 1958: Nález keramických forem na Malé Straně, Pražskou minulostí 2, 88-97.

FRÖHLICH, J., 1986: Povrchový průzkum zaniklé středověké osady Palčice - Oberflächenbesichtigung der Ortswüstung Palčice bei Písek, AVJČ 3, 91-103.

- 1989: Sklárny střrední Šumavy. Výsledky archeologického průzkumu. Sušice.

- 1990: Vesnice zaniklé roku 1579 v oboře u Kratochvíle - Die 1579 im Gehege von Kratochvíl bei Netolice in Südböhmen verwüsteten Dörfer, AVJČ 7, 151-160.

- 1993: Archeologický výzkum šumavských skláren, Archeologia technica 8, 75-83.

- 1994: Renesanční sklárny na Vilémově hoře. Archeologický př́spěvek k historii rožmberské a buquoyské sklárny, JSH 63, 3-14.

- 1994a: Die Glashütten des östlichen Böhmerwaldes, Passauer Jahrbuch für Geschichte, Kunst und Volkskunde 36, 89-94. 
- 1995: Sklárny na statku Železná Ruda a v rychtách Hojsova Stráž a Hamry (výsledky archeologického průzku$\mathrm{mu})$, ČSPS CIII, 217-226.

- 1995a: Archeologický výzkum skláren v okolí Kašperských Hor, Vlastivědné zprávy Muzea Šumavy 3, 94-118.

- 1996: K lokalizaci skláren v Novohradských horách, JSH 55, 3-10.

- 2000: Historická opevnění jižní zemské hranice, Výběr XXXVII, 285-290.

- 2006: Poloha a podoba popravišt' prácheňského kraje - Lage und Gestalt der Richtplätze des Prachiner Bezirkes, ASČ 10, 945-959.

- 2015: Šumavské páteř́ikové hutě - Patterlhütten im Böhmerwald, ASČ 19, 431-438.

FRÖHLICH, J.-KYPTA, J., 2010: Nález raně novověké keramiky u Uzenic na Blatensku - Ein Fundkomplex frühneuzeitlicher Keramik bei Uzenice im Gebiet von Blatná, AVJČ 23, 297-304.

FRÖHLICH, J.-PAVLÍK, Č., 2014: Gotické a renesanční reliéfní kachle ze sbírky Městského muzea v Týně nad Vltavou, JSH 36, 362-388.

- 2015: Gotické a renesanční kachle ze sbírky muzea v Netolicích - Gothic and Renaissance stove tiles from the collection of the museum in Netolice, ASČ 19, 367-378.

FROLEC, V., 1980: Krevní knihy jako pramen etnografického studia, SPFFBU C 27, 315-325.

FROLÍK, J., 2007: Jesuit college in Kutná Hora: courtyards and their facilities in the 17th-19th century. Archaeological excavations 1998-2005, Studies in Post-Medieval Archaeology 2, 43-56.

- 2013: Archeologický výzkum bývalé Jezuitské koleje v Kutné Hoře - The archaeological excavation in the grounds of the former Jesuit college in Kutná Hora, ASČ 17, 779-791.

- 2014: Archeologický výzkum v areálu bývalé jezuitské koleje v Kutné Hoře - Die Archäologische Grabung im Areal des ehemaligen Jesuitenkollegs in Kutná Hora in den Jahren 1998 bis 2012, AH 39, 703-722.

FROLÍK, J.-PECINOVSKÁ, M.-VEPŘEKOVÁ, J., 2015: Nález rituální lázně - mikve - v Chrudimi. Záchranný archeologický výzkum na Jánském předměstí v roce 2013 - Der Fund eines rituellen jüdischen Tauchbades einer Mikwe - in Chrudim: die archäologische Rettungsgrabung in der Johannesvorstadt im Jahr 2013, AH 40, 895-912.

FROLÍK, J.-SIGL, J., 1990: Soubor pozdně středověké keramiky z Chrudimi - Husovy ulice - A group of late medieval pottery from the town of Chrudim (Husova Street), Studies in Post-Medieval Archaeology 1, 269-284.

FRÝDA, F., 1979: Archeologický výzkum ve městě Plzni - Archäologische Forschung in der Stadt Plzeň (Pilsen), AH 4, 319-322.

- 2014: Zaniklá sklárna Stará Hut’ u Podlesí (Vogelsang), k. ú. Lídlovy Dvory, o. Klatovy, AZČ 8, $144-154$.

FUNK, L., 2010: Návrh metodiky nedestruktivního výzkumu vesnic zaniklých po roce 1945, Acta Fakulty filozofické Západočeské univerzity v Plzni 5/4, 267-279.

GABRIEL, F., 1994: Středověká pec ve Zbečně čp. 22, PRP 1, 21-22.

GALUSOVÁ, L., 2007: Zaniklý Mašův mlýn - Die verschwundene Maschamühle. In: Dějiny staveb 2006. Sborník příspěvků z konference Dějiny staveb 2006, 201-204. Plzeň.

- 2010: Archeologický nedestruktivní výzkum vodních děl zaniklých po roce 1945, Acta Fakulty filozofické Západočeské univerzity v Plzni 5/4, 281-302.

GOJDA, M., 1997: Letecká archeologie v Čechách. Praha.

- 2000: Archeologie krajiny. Vývoj archetypů kulturní krajiny. Praha.

GOJDA, M.-JOHN, J. a kol., 2013: Archeologie a letecké laserové skenování krajiny. Plzeň.

GOJDA, M.-HLADKÝ, J.-JANÁL, J.-JANČO, M.-MILO, P.-LISÁ, L.-PETŘÍK, J.-PROKEŠ, L., 2015: Archeologický výzkum památek zahradního umění. Praha.

GRABOLLE, R.-MATOUŠEK, V.-MEDUNA, P.-SMRŽ, Z., 2009: Die Schlacht bei Třebel/Triebl im Jahr 1647 und weitere Untersuchungen zur Archäologie des Krieges in der Tschechischen Republik. In: Schlachtefelderarchäologie / Battlefield Archeology. 1. Mitteldeutscher Archäologentag vom 09. bis 11. Oktober 2008 in Halle (Saale). Tagungen des Landesmuseums für Vorgeschichte Halle 2 (Meller, H., ed.), 173-186. Halle (Saale).

GRAVES-BROWN, P. M., 2000: Matter, Materiality and Modern Culture. London - New York.

GRAVES-BROWN, P. M.-HARRISON, R.-PICCINI, A., 2013: The Oxford Handbook of the Archaeology of the Contemporary World. Oxford.

HÁJEK, J.-KUBÜ, F.-MATOUŠEK, V., 1992: Srážka u Nebes. Sborník příspěvků z komplexního výzkumu vojenské epizody ze sedmileté války. Cheb.

HAJN, I.-CHVOJKA, O.-MAJER, A., 2004: Nové poznatky o přepřahací stanici koněspřežné dráhy v Bujanově, okr. Český Krumlov - Neue Erkentnisse zur Umspannstation an der Pferdeeisenbahn in Bujanov, Kr. Český Krumlov, AVJČ 17, 267-278.

HANÁKOVÁ, H.-MARTINEC, V.-VYHNÁNEK, L., 1975: Barokní pohřby od kostela sv. Jindřicha na Novém Městě pražském, SbNM B XXXI, č. 1-2, 91-107.

HANÁKOVÁ, H.-STLOUKAL, M., 1988: Pohřebiště kolem bývalého kostela svatého Benedikta v Praze. Praha.

HARRISON, R.-SCHOFIELD, J., 2010: After Modernity. Archaeological Approaches to the Contemporary Past. Oxford. 
HARTMANOVÁ, O., 2005: Budní hospodářství v Krkonoších z pohledu archeologie - Die Baudenwirtschaft im Riesengebirge aus archäologischer Sicht, PA XCVI, 165-204.

HASIL, P.-NOVÁK, D.-HASIL, J., 2015: Smrt dolu Sauersack/Rolava (okres Sokolov). Zánik důlního závodu v mezioborové perspektivě - Der Tod der Grube Sauersack (Rolava), Bez. Sokolov (Falkenau). Der Untergang eines Bergwerkbetriebes aus fachübergreifender Sicht, AH 40, 179-206.

HAVEL, J., 1980: Hromadný hrob bělohorských bojovníků - Ein Massengrab der Krieger vom Weißen Berg (Bílá hora), Archaeologica Pragensia 1, 227-231.

HAZLBAUER, Z., 1988: Gotické a renesanční kachle z hradu Točníku. Zprávy Československé společnosti archeologické 33. Praha.

- 1990: An interesting chambre-type stove tile with bas-relief decoration from the castle Točník, Studies in PostMedieval Archaeology 1, 203-210.

- 1997: Pestře glazovaná kamna z Hrubé Skály. In: Život v archeologii středověku, 215-226. Praha.

- 1998: Zobrazení antické bohyně Démétér (Ceres) na českém renesančním kachli, MVP - ČSPS 36/106, $141-144$.

- 2000: Signovaná a datovaná matrice horažd’ovického hrnčíře Josefa Dobředěleje - Die signierte und datierte Kachelform des Horažd'ovicer Hafners Josef Dobředělej, AH 25, 389-396.

HAZLBAUER, Z.-DURDÍK, T., 1996: Neobvyklý manýristický kachel s alegorií ohně z hradu Křivoklátu Ungewöhnliche manieristische Kachel mit der Allegorie des Feuers von der Burg Křivoklát, CB 5, $246-254$.

HAZLBAUER, Z.-GLOSOVÁ, M.-VOLF, P., 1996: Stavební rekonstrukce dobových kamen v Muzeu Komenského v Přerově, VVM XLVIII, 394-402.

HAZLBAUER, Z.-HLAVÁČEK, J., 1997: Početný pozdně renesanční kachlový soubor z hradu Rýzmburku, okres Náchod, Východočeský sborník historický 23, 123-135.

HAZLBAUER, Z.-ŠPAČEK, L., 1986: Poznámky k výrobě reliéfních renesančních kachlů s přihlédnutím k nálezům ve středním Polabí, ČNM A 155, 146-166.

HAZLBAUER, Z.-WALDHAUSER, J., 1998: Pozůstatky historických kachlových kamen z doby Václava Budovce z Budova ze zámku v Mnichově Hradišti - The remains of a historic stove tile from the time of Václav Budovec of Budov, from the château at Mnichovo Hradiště, ASČ 2, 425-432.

HEJDOVÁ, D., 1981: The Glasshouse at Rejdice in Northeastern Bohemia. Late Sixteenth-Early Seventeenth Centuries, Journal of Glass Studies 23, 18-33.

HIMMELOVÁ, Z.-PROCHÁZKA, R., 1990: On the characteristic of some components of material culture and public health care of the town of Brno in the 16th-17th century, Studies in Post-Medieval Archaeology 1, 95-126.

HLÁSEK, D.-GERSDORFOVÁ, Z.-HRUŠKOVÁ, M.-PLZÁK, J.-PTÁK, M.-STEHLÍKOVÁ, E., 2014: Zaniklý dřevěný most na Otavě mezi Přeštovicemi a Štěkní (okr. Strakonice) - Eine untergegangene Holzbrücke im Fluss Otava zwischen Přešt'ovice und Štěken (Kr. Strakonice), AVJČ 27, 355-370.

HOLUB, P.-JORDÁNKOVÁ, H.-LOSKOTOVÁ, I., 2009: Early Modern period Brno stove tiles with a mosaic (Tapestry) pattern, Studies in Post-Medieval Archaeology 3, 479-500.

HRDLIČKA, L.-RICHTER, M., 1974: Slovanské a středověké osídlení Oškobrhu - Die slawische und mittelalterliche Besiedlung auf dem Oškobrh bei Poděbrady, PA LXV, 111-184.

HRUBÝ, P.-HEJHAL, P.-KAŠÁK, K.-MALÝ, K.-VALKONY, J., 2009: The deserted baroque glassworks in the cadastral territory of Nová ves near Božejov (District of Pelhřimov), Studies in Post-Medieval Archaeology 3, 479-500.

HUML, V., 1971: Nález renesanční keramiky v Praze na Slovanech - Ein Renaissancekeramikfund aus Prag "Na Slovanech", AR XXIII, 479-500.

- 1975: Vodovodní sít' na Václavském náměstí v Praze v 15.-17. století, Český lid LXII, 223-230.

- 1979: Archeologické poznámky k dějinám Koňského trhu na Novém Městě pražském, Staletá Praha IX, 158$173,327-328$.

- 1982: K archeologickému výzkumu agrárního zázemí Prahy (Litochleby, Horní Počernice a Ovenec-Bubeneč) - Zur archäologischen Untersuchung des landwirtschaftlichen Hinterlands von Praha (Prag) - Litochleby, Horní Počernice und Ovenec-Bubeneč, AH 7, 211-224.

- 1989: Archeologický výzkum zástavby býv. biskupského dvora u sv. Petra na Poříčí (Praha 1 - Nové Město), Archaeologica Pragensia 10, 205-257.

HŮRKOVÁ, J. a kol., 2015: Archeologický výzkum panského sídla v Chanovicích. Klatovy.

CHARVÁTOVÁ, K.-CHARVÁT, P., 1981: Keramika 16. století z Prahy-Karlova, Praehistorica 8 - Varia Archaeologica 2, 333-336.

CHMIELOWIEC, S.-KAŠPAR, V.-ZDANIEWICZ, R., 2013: Sedláci a vojáci: nálezy militarií a železných nožů ze záchranného archeologického výzkumu dvou středověkých a novověkých hospodářských dvorů v PrazeVokovicích - Peasants and soldiers: Finds of militaria and iron knives from the rescue excavation of two medieval and modern period homesteads in Prague-Vokovice, ASČ 17, 275-314.

CHVOJKA, O.-MENŠÍK, P., 2013: Archeologický a historický výzkum koněspřežné dráhy v jižních Čechách. In: Archeologie Modernity. Př́ístupy - metody - témata (Vařeka, P., ed.), 91-98. Plzeň. 
CHYBOVÁ, H.-VÁLKA, M., 1994: Nález novověké keramiky z přelomu 16.-17. století na dvoře rottalovského domu v Kroměříži, Český lid LXXXI, 323-331.

JANSKÁ, E., 1966: Hromadný hrob bělohorských bojovníků, Staletá Praha II, 107-110, 274.

JORDÁNKOVÁ, H.-SEDLÁČKOVÁ, H., 2004: Sklo a keramika z tabule Matouše Židlochovického v Brně, BMD 18, 205-219.

JUŘINA, P. a kol., 2005: Předběžná zpráva o výsledcích plošného archeologického výzkumu v areálu bývalých kasáren Jiřího z Poděbrad na Náměstí republiky v letech 2003-2006 - Preliminary report on the results of the 2003-06 open-area archaeological excavations in the area of the former George of Poděbrady barracks on náměstí Republiky, Archaeologica Pragensia 17, 211-232.

JUŘINA, P.-KAŠÁK, K.-SAMOJSKÁ, K., 2007: The discovery of an Early Modern bell foundry on Jungmann Street in the New Town in Prague, Studies in Post-Medieval Archaeology 2, 117-136.

JUŘINA, P.-VYŠOHLÍD, M., 2009: The Capuchin Monastery on náměstí Republiky (Republic Square) in Prague, Studies in Post-Medieval Archaeology 3, 365-390.

JUSTOVÁ, J., 1981: Výzkum libického předhradí. In: Turek, R.-Hásková, J.-Justová, J., LIVBVZ METROPOLIS. Tam, kde řeka Cidlina tratí své jméno. Libice nad Cidlinou.

- 1985: Archeologický výzkum na předhradí slovanského hradiště v Libici nad Cidlinou a v jeho zázemí v letech 1980-1984. Předběžná zpráva - Archaeological research in the bailey of the Slav hill-fort at Libice nad Cidlinou and in its hinterland in 1980-1984 (preliminary report), AR XXXVII, 308-318, 357-360.

- 2002: Chalupovský manský dvůr v Libici nad Cidlinou. Archeologický prŕíspěvek k poznání středověké a novověké vsi Libice. Č́st II. - Der Hof des Vassalehauses „Chalupovský“ in Libice an der Cidlina. Archäologischer Beitrag zur Erkenntnis des mittelalterlichen und frühneuzeitlichen Dorfes Libice. Teil II, CB 8, 381-392.

KALFERST, J., 1994: Záchranný výzkum synagogy v Rychnově nad Kněžnou, ZMHK 20, 142-144.

KALFERST, J.-SIGL, J., 1990: Archeologický výzkum „Staré boudy“ na k. ú. Špindlerův mlýn v Krkonoších, Zpravodaj Krajského muzea východních Čech 17, 78-89.

KAVAN, J., 1982: Výsledky archeologického výzkumu Karlovy hutě v Jizerských horách, která pracovala v letech 1758-15, Ars vitraria 7, 19-72.

KLÁPŠTĚ, J.-MUK, J., 1988: Studie o středověkém domě z Mostu (čp. 226) - Eine Studie über das mittelalterliche Haus aus Most (Nr. 226), PA LXXIX, 199-240.

KLÍR, T., 2008: Osídlení zemědělsky marginálních půd v mladším středověku a raném novověku. Praha.

KLÍR, T.-BERÁNEK, M., 2012: A social-economic interpretation of the layouts of deserted villages. An example of deserted village at the "V Žáku" site in Klánovice Forest in Prague, Studies in Post-Medieval Archaeology 4, 289-364.

KOČÁR, P.-BENEŠ, J.-PREUSZ, M.-VANĚČEK, Z., 2015: Ječmen a ječný slad ve středověku a raném novověku v českých zemích, Kvasný průmysl 61/5, 153-158.

KOČÁR, P.-JANKOVSKÁ, V.-STAREC, P.-HUML, V., 2007: Paleobotanická analýza novověkého antropogenního sedimentu z Prahy, Melantrichovy ulice čp. 465-I. In: Ve službách archeologie 2. Př́ŕrodovědné metody $\mathrm{v}$ archeologii a antropologii (Hašek, V.-Nekuda, R., edd.), 26-37. Brno.

KOČÁR, P.-KOČÁROVÁ, R.-SƯVOVÁ, Z.-PETR, L., 2009: The Early Modern period cesspit at the Capuchin Monastery on the site of Prague's Republic Square from the perspective of environmental archaeology, Studies in Post-Medieval Archaeology 3, 391-406.

KOČÁR, P.-SŮVOVÁ, Z.-KOČÁROVÁ, R.-KYNCL, T., 2007: Environmental analyses of the content of a Renaissance cesspit from Malá Strana in Prague, Studies in Post-Medieval Archaeology 2, 383-400.

KORENÝ, R.-KYPTA, J.-ŠULC, J., 2003: Pozdně gotické a renesanční kachle ze Svatého Pole. Př́ispěvek k poznání hmotné kultury venkovské fary - Die spätgotische und renaissancenzeitliche Offenkacheln aus Svaté Pole. Der Betrag zur Erkenntnis der materiellen Kultur des Landpfarrhauses, ASČ 7, 720-733.

KOSŇOVSKÁ, J.-HOUFKOVÁ, P.-KOVÁŘ, D., 2011: Lannova třída v Českých Budějovicích ve světle archeobotanických analýz a historických pramenů - Lannova street, České Budějovice, based on archaeobotanical analyses and historical sources, AVJČ 24, 263-280.

KOULA, J., 1917: Co nám vyprávějí pražské střepy 17. století, PA XXIX, 12-16, 123-129, 176-184, $250-257$.

- 1918: Co nám vyprávějí pražské střepy 17. století, PA XXX, 27-34, 101-108.

- 1919: Co nám vyprávějí pražské střepy 17. století, PA XXXI, 25-27.

KOVÁČIK, P.-VESELÁ, P., 2009: Stove tiles from Starý Bohumín, Studies in Post-Medieval Archaeology 3 , 289-302.

KOVÁRNÍK, J.-HORÁČKOVÁ, L.-VARGOVÁ, L.-MUCHA, L.-VACHUNKOVÁ, A., 2006: Hromadné hroby vojáků na Brněnské ulici z bitvy u Znojma v roce 1809. In: Ve službách archeologie 7 (Hašek, V.-Nekuda, R.Ruttkay, M., edd.), 313-328. Brno.

KOVÁŘ, D., 2009: Historická popraviště Bechyňského kraje. Přehled a zhodnocení průzkumu z let 2006-2009Historische Richtplätze des Bechiner Kreises. Übersicht und Auswertung der Prospektionen in den Jahren 2006-2009, AVJČ 22, 177-259.

- 2014: Historická těžba a zpracování vápence na Českobudějovicku. Výsledky povrchového průzkumu pozůstatků novověkého vápenictví a výpověd’ archivních pramenů - Historische Förderung und Bearbeitung des 
Kalksteins im Gebiet von České Budějovice. Ergebnisse der Oberflächenprospektionen der neuzeitlichen Kalkproduktionsobjekte sowie Aussage der schriftlichen Quellen, AVJČ 27, 307-354.

KOVÁŘ, D.-KYPTA, J.-ŠULC, J., 2014: Architektura jako výraz sociálního vzestupu. Př́íklady z venkovského prostředí sklonku středověku a počátku novověku, PRP 21, č. 2, 3-20.

KRAJÍC, R., 1998: Dům pasíře Prokopa v Táboře. Archeologický výzkum odpadní jímky v domě čp. 220. Tábor.

- 2003: Soubor renesančního skla z táborského domu čp. 308 (předběžné sdělení), Historické sklo 3, $103-107$.

- 2006: Dům rodiny Vaverkových na táborském náměstí. Př́spěvek k dějinám řemesla a obchodu na sklonku středověku, Husitský Tábor 15, 249-269, 286-313.

- 2007: Archeologie postmedieválního období. Současný stav a perspektivy výzkumu v jižních Čechách. In: Archeologie na pomezí. AVJČ - Supplementum 4, 137-174. České Budějovice.

- 2009: Voda a odpady jako privátní i komunální problém městských aglomerací. Doklady z města Tábora od 13. do 18. století - Wasser und Abfall als privates und kommunales Problem städtischer Agglomerationen. Belege aus der Stadt Tábor, 13.-18. Jahrhundert, PA C, 261-300.

KRAJÍC, R.-PODLISKA, J.-SEDLÁČKOVÁ, H.-VESELÁ, J., 2005: Renesanční sklo v archeologických nálezech v Čechách a na Moravě. In: Historie sklářské výroby v českých zemích. I. díl. Od počátkủ do konce 19. století (Drahotová, O., ed.), 159-190. Praha.

KRASNOKUTSKÁ, T., 2005: Středověké a novověké kachle z Opavy. Katalog nálezů z archeologických výzkumů. Archaeologiae Regionalis Fontes 8. Olomouc.

KRÁSNÝ, F.-KYPTA, J.-ŠULC, J., 2005: Pozdně gotické nálezy ve venkovských usedlostech v Čisté u Mladé Boleslavi - Spätgotische Funde in ländlichen Anwesen in Čistá bei Mladá Boleslav, ASČ 9, 643-652.

KUBU゚, F.-ZAVŘEL, P., 1988: Pozůstatky valového opevnění rakouské armády v bitvě u Zahájí dne 22. 5. 1742, AVJČ 5, 183-190.

- 2007: Zlatá stezka. Historický a archeologický výzkum významné středověké obchodní cesty. 1. Úsek Prachatice - státní hranice. České Budějovice.

KUNA, M. a kol., 2004: Nedestruktivní archeologie. Teorie, metody a cíle. Praha.

KUNA, M.-VAŘEKA, P., 2007: Archeologický odkryv. In: Archeologie pravěkých Čech 1. Pravěký svět a jeho poznávání (Kuna, M., ed.), 94-97. Praha.

KUNDERA, L.-MĚŘÍNSKÝ, Z., 1987: Nález keramiky z poloviny 16. století v Dolních Věstonicích (okr. Břeclav), ČMMZ LXXII, 155-161.

KYPTA, J.-PEŠTA, J.-ŠULC, J.-VESELÝ, J., 2008: Dějiny a stavební podoba renesančního mlýna v městečku Lázen̆ Toušeň, PRP 15, č. 1, 71-88.

KYPTA, J.-ŠULC, J., 2003: Poznámky ke stavební podobě vesnic středního Polabí v předbělohorském období (Usedlost s renesanční bránou v Podolance), PSČ 17, 25-32.

- 2004: K formám pronikání slohových výtvarných prvků do prostředí venkovské usedlosti (Pozdně gotické brány v Jenštejně a Dřevčicích), PSČ 18, 25-39.

- 2005: Pozdně gotické slohové prvky v architektuře venkovských usedlostí v Záluží u Čelákovic, PSČ 19, 46-53.

- 2006: Kachle ze dvora Votelež u Kouřimi. Ke kultuře bydlení v hospodářském dvoře na přelomu středověku a raného novověku, PSČ 20,3-29.

- 2007: Renesanční brány venkovských usedlostí ve Skalsku a Nosálově. In: Confluens. Sborník historických a vlastivědných prací z Mělnicka 6, 15-29. Mělník.

KYPTA, J.-ŠULC, J.-VESELÝ, J., 2005: Pozdně gotické kamenické prvky ve venkovských usedlostech na Nymbursku. Průzkumy vybraných usedlostí v lokalitách Vykáň, Černíky a Kounice, PRP 12, č. 2, 97-120.

LANDSFELD, H., 1947: Co vyráběli novokřtěnští keramikové v Podivíně, Vlastivědný sborník moravský 2, 222-238.

- 1950: Lidové hrnčířství a džbánkařství. Praha.

- 1953: Výroba habánské keramiky ve světle vykopávek, Český lid XL, 205-212.

- 1971: Habánská hrnčina - neznámá keramika 16. a 17. století. In: Př́́spěvky k dějinám skla a keramiky 1. Rozpravy NTM 45, 35-58. Praha.

LEMINGER, E., 1902-1903: Zpráva o nálezu starožitných výrobků hrnčířských v Kutné Hoře, PA XX, 65.

- 1926: Umělecké řemeslo v Kutné Hoře. Rozpravy České akademie věd a umění. Tř. 1, č. 71. Praha.

LIKOVSKÝ, J.-VELEMÍNSKÝ, P., 2006: Lidské kostrové pozůstatky z popraviště ve Vodňanech, AR XVIII, $810-812$.

LIŠKA, A., 1958: Nález středověké keramiky v ulici Politických vězňů v Praze, Pražskou minulostí 2, 36-41.

LOKVENC, T.-BARTOŠ, M.-ŠVEC, J., 1973: Nález zbytků zapomenuté boudy nedaleko labského pramene, Krkonoše 1973, 8-10.

LOSKOTOVÁ, I., 1999: Př́íspěvek k hrobové výbavě 17.-18. století, Pravěk NŘ 9, 423-430.

- 2012: Brněnské kachle se starozákonními hrdiny - Brünner Kacheln mit alttestamentarischen Helden, AH 37, 663-678.

LOSKOTOVÁ, I.-HANÁK, V., 1995/1996: Švédský zákop před Brnem, Forum brunense 7, 143-151.

MALÍK, P.-PEŠKA, M., 1994: Soubor časně novověké keramiky z Moravského Krumlova, SPFFBU E 39 , 93-110. 
MALINA, O., 2014: LiDAR a hornická krajina. Terénní památky v novém světle, ZPP 74, 124-132.

- 2015: Poznámky k hornické krajině jáchymovského revíru - Anmerkungen zur Montanladschaft des Reviers von Jáchymov (Joachimsthal), AZČ 9, 147-163.

- 2016: Památkový underground: historická podzemní důlní díla, možnosti poznání a ochrany jejich hodnot, ZPP $76,617-626$.

MALINA, O.-KAREL, T., 2012: Hřebečná - možnosti a východiska studia hornické krajiny, Sborník muzea Karlovarského kraje 20, 353-361.

MALINA, O.-URBAN, M., 2013: Vodní hospodářství v cínovém revíru Hřebečná. In: Proměny montánní krajiny. Historické sídelní a montánní struktury Krušnohoří (Karel, T.-Kratochvílová A., edd.), 162-179. Loket.

MAŠEK, N., 1966: Soubor keramiky a středověký zděný objekt z Jindřišské ulice v Praze - Die Keramikgarnitur und das gemauerte Objekt aus der Jindřišská-Straße in Prag, AR XVIII, 132, 202-203.

MAŠKOVÁ, P.-MICHÁLEK, J., 2006: Archeologický výzkum v poloze „Na Šibenici“ ve Vodňanech (okres Strakonice). Př́íspěvek k archeologii popravišt’ v Čechách - Archäologische Grabung in der Flur ,Na šibenici“ (,Am Galgen“) bei Vodňany (Bezirk Strakonice). Ein Beitrag zur Archäologie der Hinrichtungsstätten in Böhmen, AR XVIII, 790-809.

MATIEGKA, J.-MALÝ, J.-BERGL, J., 1934: Tělesná povaha Albrechta z Valdštejna. Praha.

MATOUŠEK, V., 1991: Archeologie novověku, nebo novověká archeologie? Folia historica Bohemica 15, 41-58.

- 1992: Archeologie současnosti v jeskyních Českého krasu, Český lid LXXIX, 420-439.

- 2006: Třebel. Obraz krajiny s bitvou. Praha.

- 2010: Čechy krásné, Čechy mé. Proměny krajiny Čech v době industriální. Praha.

- 2011: Archeologický výzkum novověku a moderní doby v České republice. Několik poznámek k historii, současnému stavu a perspektivám, Historická sociologie 2, 37-58.

- 2011a: Terénní studium bojišt' třicetileté války na území České republiky. In: Bitva u Rakovníka 1620, 72-80 (Blažková, K., ed.). Rakovník.

-2012: Archäologische Erforschung der Schlachtfelder des Dreißigjährigen Krieges auf dem Gebiet der Tschechischen Republik. In: Die blut'ge Affair' bei Lützen (Schuberth, I.-Reichel, M., edd.), 283-293. Wettin-Löbejün.

- 2014: Nenápadný půvab (české) buržoazie. Počátky masové a individuální rekreace v Čechách v době industrializace pohledem historika. In: Individuální a masová rekreace v okolí velkých industriálních měst v 19.-21. století (Blažková, T.-Fialová, D.-Matoušek, V., edd.), 11-28. Praha.

- 2015: Archeologie novověku - univerzální disciplína pro studium třicetileté války, průmyslové revoluce i současné konzumní společnosti?, Hospodářské dějiny 28/1, 67-86.

- 2015a: Poznámky k terénnímu studiu polních opevnění ze 17.-19. století. Zkušenosti z českých zemí - Anmerkungen zum Terrainstudium der Feldbefestigungen des 17.-19. Jahrhunderts. Erfahrungen aus den Ländern Tschechiens, AZČ 9, 70-82.

- 2015b: Vzorné letovisko Hradištko. Vznik a prvé desetiletí meziválečného letoviska na soutoku Vltavy a Sázavy, HG 41, 47-81.

MATOUŠEK, V.-BLAŽKOVÁ, T., 2012: The image and reality of battlefields from the Thirty Year's War. A preliminary report on a project for the systematic study of engravings of the battlefields from the Thirty Year's War in the territory of the Czech Republic, Studies in Post-Medieval Archaeology 4, 269-288.

MATOUŠEK, V.-BLAŽKOVÁ, T., edd., 2015: Les a industrializace. Praha.

MATOUŠEK, V.-HÁJEK, J.-KUBŮ, F.-MEDUNA, P., 1990: A complex investigation of a field fortification of the Seven Years War (1756-1763) at the site of Nebesa by Aš (Asch), Studies in Post-Medieval Archaeology 1, 29-61.

MATOUŠEK, V.-HOLÝ, P., 2007: Horní Víska, Tachov district, West Bohemia. Archaeological and geobotanical investigation of deserted village, Studies in Post-Medieval Archaeology 2, 343-360.

MATOUŠEK, V.-KOUKALOVÁ, Š.-ŠÁŠINKOVÁ, M., 2014: Letní a celoročně obývané vily a villegiatury v okolí Prahy na konci 19. a v prvých desetiletích 20. století. Př́íspěvek k proměnám krajiny Čech v procesu modernizace české společnosti, HG 40, 19-40.

MATOUŠEK, V.-KOVANDOVÁ, M., 2005: Terénní dokumentace Švédské šance nad hradem Kynžvartem, Sborník Chebského muzea 2004, 61-66.

MATOUŠEK, V.-SCHEUFLER, V., 1980: Nálezy novověké keramiky v Berouně, Vlastivědný sborník Podbrdska $18,53-57$.

- 1983: Raně novověké berounské zboží ve světle archeologických výzkumů v Berouně - Frühneuzeitliche Berouner Waere im Lichte archäologischer Forschung, AH 8, 189-196.

MATOUŠEK, V.-SCHEUFLER, V.-ŠTAJNOCHR, V., 1985: Berounské majoliky, ČNM A, 154, 126-139.

MEDUNA, P., 1990: Morphology of field fortifications of the 17th-19th centuries. A contribution to surface research, Studies in Post-Medieval Archaeology 1, 75-86.

MEDUNA, P.-KYPTA, J.-ŠULC, J.-MATĚJEK, M., 2001: Vidim a Daminěves. Poznámky k vývoji středověké a novověké vesnice - Vidim and Daminěves, notes on the development of Medieval and Early Modern villages, ASČ 5, 689-720.

MEHLER, N., 2013: Breaking new ground: historical archaeology in Central Europe. In: Historical Archaeology in Central Europe (Mehler, N., ed.), 11-29. Rockville. 
MĚCHUROVÁ, Z., 2012: Pásové řetězy ze sbírek Moravského zemského muzea v Brně jako archeologický doklad renesančního užitého umění - Bandketten aus den Sammlungen des Mährischen Landesmuseums in Brno als archäologischer Beleg für die angewandte Kunst der Renaissance, AH 37, 747-767.

MENOUŠKOVÁ, D.-MĚŘÍNSKÝ, Z., edd., 2008: Krása, která hřeje. Výběrový katalog gotických a renesančních kachlů Moravy a Slezska - Schönheit, die wärmt. Gotische und renessainzeitliche Kacheln aus Mähren und Schlesien. Uherské Hradiště.

MERTA, J., 1980: Průmyslová archeologie. In: Zkoumání výrobních objektů a technologií archeologickými metodami, 5-8. Brno.

MERTA, D.-PEŠKA, M., 2009: The remnants of a feast or housecleaning at Staroměstská Street no. 8? On the typology and chronology of Brno goblets, Studies in Post-Medieval Archaeology 3, 93-104.

MĚŘÍNSKÝ, Z., 1979: Záchranné archeologické výzkumy na Moravě a ve Slezsku z období 6.-16. století v letech 1970-1978 - Archäologische Notgrabungen an mährischen und schlesischen Fundstätten aus dem 6.-16. Jahrhundert in den Jahren 1970-1978, AH 4, 55-71.

MICHÁLEK, J., 2006: Topograficko-archeologický průzkum a výzkum šibenic v okrese Strakonice v letech 1995-2005 (Předběžná zpráva) - Topographisch-archäologische Forschungen und Grabungen an den Galgenanlagen im Kreis Strakonice in den Jahren 1995-2005 (Vorbericht), AVJČ 19, 303-324.

MICHNA, P. J., 1977: Archeologický průzkum historického jádra města Olomouce, ulice Barvířské. Předběžná zpráva o první etapě - Die archäologische Erforschung des Stadtkerns von Olmütz, der Färbergasse (Vorbericht über die erste Forschungsetappe), AH 2, 271-281.

MILITKÝ, J.-VAŘEKA, P., 1997: Češnovice: Archeologický výzkum středověké a novověké vesnice na Českobudějovicku I. Pozdně středověký dům v usedlosti čp. 13 - Archaeological research of the present-day village of the medieval origin I. The late medieval house within the farm No. 13, AVJČ 10, 1997, 58-79.

MOTYKOVÁ, K.-HAZLBAUER, Z., 1999: Archeologický výzkum v areálu bývalého konventu v Lysé nad Labem. Č́st I. Nález manýristických kachlů se zobrazením evangelisty Jana a jejich širší historický význam Archaeological excavations in the grounds of the former convent at Lysá nad Labem. Part I: mannerist glazed tiles depicting John the Evangelist and their wider historical significance, ASC̆ 3, 569-579.

MOTYKOVÁ, K.-SEDLÁČKOVÁ, H., 1996: Raně novověká zděná kanalizace objevená pod náměstím Přemyslovců v Nymburce, MVP - ČSPS 34/104, 152-159.

MOTYKOVÁ, K.-ŠENBERGER, T., 2000: Sladovnické zařízení z 16. století objevené při archeologickém výzkumu v Nymburce, ZPP 60, 268-272.

MUK, J.-HUS, M., 1985: Objev pozdně středověké pece mincovny v Jáchymově - Die Entdeckung eines spätmittelalterlichen Ofens der Münzstätte in Jáchymov (Joachimsthal), AH 10, 235-237.

MUSIL, J., 2008: Soubor raně novověkých hliněných dýmek z Hradební ulice v Chrudimi, Chrudimský vlastivědný sborník 12, 3-35.

- 2010: Nález raně novověké prachovnice z Chrudimi Hradební ul., Východočeský sborník historický 18, 85-92.

- 2011: Raně novověké kovové článkové ženské opasky (tzv. Brautgürtel), Východočeský sborník historický 20, 21-52.

- 2015: Nález kolečkového zámku palné zbraně z hradu Košumberka (okr. Chrudim) - Befund des Radschlosses der Feuerwaffe der Burg Koschumberg (Bezirk Chrudim), CB 15, 94-105.

NECHVÁTAL, B., 1966: Záchranná akce ve Struhách u Nymburka - Die Rettungsgrabungen in Struhy bei Nymburk, AR XVIII, 203-207.

- 1968: Studie o hrnčířství a keramice 16. století v Čechách. Kandidátská disertace. Praha.

NENUTIL, J.-RAK, M. a kol., 2011: Exhumace obětí II. světové války. Předpoklady, východiska, výzkum. Plzeň.

NENUTIL, J.-RAK, M.-FRIEDL, L.-FUNK, L.-HLOŽEK, J.-MARKOVÁ, S.-MENŠÍK, P.-NETOLICKÝ, P., 2011: Archeologický výzkum na městském hřbitově ve Stříbře. In: Nenutil, J.-Rak, M. a kol., Exhumace obětí II. světové války. Předpoklady, východiska, výzkum, 79-82. Plzeň.

NEUSTUPNÝ, E., 2013: Archeologie modernity - teoretický kontext. In: Archeologie 19.-20. století. Př́istupy témata - metody (Vařeka, P., ed.), 13-16. Plzeň.

NOVÁČEK, K., 1997: Př́iklad interpretace historického vývoje mikroreliéfu: Bdeněves u Plzně - An example of the interpretation of historical development of the micro-relief: Bdeněves near Plzeň, AR XLIX, 495-503.

NOVÁČEK, K.-VAŘEKA, P., 1994: Libkovice, okr. Most - záchranný archeologický výzkum (předběžná zpráva), PA - Supplementum 2, 223-224.

- 1996: Archaeological research of present - day villages of a medieval origin in Bohemia, Ruralia I, PA Supplementum 5, 314-316.

- 1997: Archeologický výzkum žijících vesnic středověkého původu v Čechách - Archaeological research of present-day villages of a medieval origin in Bohemia, ASČ 1, 429-444.

NOVOTNÝ, B., 1959: Hromadný nález ze 16. stol. v Brně. In: Fontes archeologicae Moraviae. Prameny moravské archeologie. Tom I. Brno.

OMELKA, M.-̌̌EBOUNOVÁ, O., 2008: Soubor korálků ze zaniklého hřbitova při kostelu sv. Jana v Oboře (Praha-Malá Strana) - A collection of beads from the defunct cemetery at the Church of St. John the Baptist in Obora, Prague-Malá Strana, ASČ 12, 887-962. 
- 2012: Soubor medailonů a feniků se symbolikou sv. Benedikta ze zaniklého hřbitova při kostelu sv. Jana v Oboře (Praha-Malá Strana) - A collection of medallions and pfennigs with the symbols of St. Benedict from the defunct cemetery at the church of St. John in Obora (Prague-Lesser Town), ASČ 16, 983-1019.

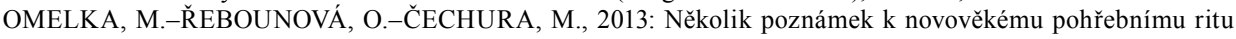
na př́kladu hrobových nálezů poutních medailonů z kostela sv. Jana Křtitele v Jindřichově Hradci - Einige Anmerkungen zum neuzeitlichen Bestattungsritus am Beispiel von Pilgermedaillons in Grabfunden aus der Johannes-der-Täufer-Kirche in Jindřichův Hradec (Neuhaus), AH 38, 379-397.

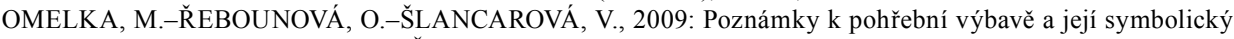
význam pro obyvatele barokních Čech a Moravy - Die Bemerkungen zur Grabausstattung und ihre symbolische Bedeutung für die Bevölkerung Böhmens und Mährens im Barock, AH 34, 591-602.

- 2010: Soubor kř́žků ze zaniklého hřbitova při kostelu sv. Jana v Oboře (Praha-Malá Strana) - A collection of crosses from the defunct cemetery at the Church of St. John in Obora, Prague-Lesser Town (Praha-Malá Strana). II. Special crosses, ASČ 14, 467-520.

OMELKA, M.-ŠLANCAROVÁ, V., 2007: Soubor prstenů ze zaniklého hřbitova při kostelu sv. Jana v Oboře (Praha-Malá Strana) - A collection of rings from the abandoned graveyard around St John's Church at Obora (Prague-Malá Strana), ASČ 11, 671-710.

OPRAVIL, E., 2002: Novověké archeobotanické nálezy z Uherského Brodu, Slovácko 43, 107-114.

ORNA, J., 2005: Gotické a renesanční kachle ve sbírkách Západočeského muzea v Plzni. Plzeň.

ORNA, J.-DUDKOVÁ, V., 2016: Možnosti přiřazení předmětů z odpadních jímek v Plzni konkrétním obyvatelům města - Möglichkeiten, Gegenstände aus Pilsner Abwassergruben bestimmten Bürgern der Stadt zuzuordnen, AH 41, 2, 363-374.

PAJER, J., 1974: K metodice hodnocení lidové keramiky z archeologických nálezů, Národopisné aktuality 11, $169-184$

- 1982: Hromadný nález ze začátku 17. století ve Strážnici. Strážnice.

- 1983: Počátky novověké keramiky ve Strážnici. Strážnice.

- 1990: A hoard find of pottery from the area of the Habaner (Anabaptist) court at Strachotín, Studies in Post-Medieval Archaeology 1, 169-202.

- 1990a: On the development of a new scientific discipline - post-mediaeval archaeology. Some thoughts on its current state and its perspective, Studies in Post-Medieval Archaeology 1, 23-28.

- 1996: K počátkům habánské keramické výroby na Moravě, JM 32, 83-93.

- 2001: Novokřtěnské fajánse ze Strachotína. Mikulov.

- 2001a: Výroba novokřtěnských fajánsí na Jižní Moravě (Soupis doložených lokalit), JM 37, $21-42$.

- 2006: Studie o novokřtěncích. Strážnice.

- 2007: Archaeological excavations of Anabaptist ceramics in Moravia, Studies in Post-Medieval Archaeology 2, 227-250.

PALMER, M.-NEAVERSON, P., 1998: Industrial archaeology. Principles and practices. London - New York.

PALMER, M.-NEVELL, M.-SISSONS, M., 2012: Industrial Archaeology: A Handbook. New York.

PAVLÍK, Č.-VITANOVSKÝ, M., 2004: Encyklopedie kachlů v Čechách, na Moravě a ve Slezsku. Ikonografický atlas reliéfů na kachlích gotiky a renesance. Praha.

- 2008: Magický jednorožec a jeho ztvárnění na kachlích gotiky a renesance - Die magische Einhorn und seine Gestaltung auf Kacheln der Gotik und der Renaissance, AH 33, 539-558.

PETRÁŇ, J., ed., 1985: Dějiny hmotné kultury I (1-2). Praha.

- 1995: Dějiny hmotné kultury II (1). Praha.

- 1997: Dějiny hmotné kultury II (2). Praha.

PETRÁŇOVÁ, L.-VAŘEKA, J., 1987: Vybavení venkovské zemědělské usedlosti v době předbělohorské (na pozadí poddanských inventářů) - Die Ausstattung des Bauerngehöfts in der Zeit vor der Schlacht auf Weißen Berg (vor dem Hintergrund der Untertaneninventare), AH 12, 277-286.

PETŘÍČKOVÁ, J., 1997: Osteologické nálezy z Češnovic, okr. České Budějovice, AVJČ 10, 80-83.

PILNÁ, V.-SCHMOLLOVÁ, J., 2014: Pohřební výbava Bohunky Lobkovické ze Šternberka ve sbírkách Západočeského muzea v Plzni - Grabungstattung von Bohunka von Sternberg, geb. Lobkowicz, in den Sammlungen von Westböhmischen Museums in Pilsen, AZČ 8, 155-169.

PREUSZ, M., 2013: Pozdně renesanční umyvadlo z městského domu č. 55 na Latránu v Českém Krumlově Ein spätrenaissancezeitliches Waschbecken aus dem Haus Nr. 55 im Latrán von Český Krumlov, AVJČ 26, 287-296.

- 2015: Novověké dýmky z Českých Budějovic - Neuzeitliche Pfeifen aus České Budějovice, AVJČ 28, $307-335$.

- 2016: Novověké dýmky v jižních Čechách. Nálezy ze sbírky Jihočeského muzea v Českých Budějovicích Neuzeitliche Pfeifen in Südböhmen. Funde aus der Sammlung des Südböhmischen Museums in České Budějovice, AVJČ 29, 399-408.

PREUSZ, M.-BENEŠ, J.-KOVAČIKOVÁ, L., 2014: Der Bürger und das Tier - Ein Beitrag zur Erforschung der frühen Neuzeit in Český Krumlov/Böhmisch Krummau, Fines Transire 23, 209-221. 
PREUSZ, M.-KODÝDKOVÁ, K.-KOČÁR, P.-VANĚČEK, Z., 2015: Exotic Spices in Flux: Archaeobotanical Material from Medieval and Early Modern Sites of the Czech Lands (Czech Republic). Interdisciplinaria Archaeologica, Natural Sciences in Archaeology 6/2, 223-236.

PREUSZ, M.-PACLÍKOVÁ, K.-PTÁK, M., 2013: Zaniklá vodní díla v bývalé rožmberské oboře u Netolic (Předběžná zpráva k začínajícímu historicko-archeologickému výzkumu). In: Archeologické prospekce a nedestruktivní archeologie v Jihočeském kraji, kraji Vysočina, Jihomoravském kraji a v Dolním Rakousku. Sborník z konference, Jindřichův Hradec 6. 3. - 7. 3. 2013 (Chvojka, O., ed.), 221-229. České Budějovice.

PROCHÁZKA, R.-VAŘEKA, P., 2005: Manuál terénního archeologického výzkumu odkryvem. Popis stratigrafických jednotek. Plzeň.

RAK, M., 2011: Možnosti archeologického poznání novodobých polních fortifikací na př́íkladu lokality z 30. let 20. století - Möglichkeiten der archäologischen Erforschung neuzeitlicher Feldbefestigungen am Beispiel einer Fundstelle aus den dreißiger Jahren des 20. Jahrhunderts, AH 36, 279-288.

- 2014: Archeologie konfliktů 20. století. Aeroarcheologie. Historie - témata - metody - příklady. Plzeň.

RAK, M.-VLADAŘ, J., 2010: Focke-Wulf from Nynice - The excavation of a German Aircraft, Forum Archaeologiae. Zeitschrift für klassische Archäologie 14/55.

RENNER, J., 1912: Srážka císařských a královských vojsk u Rakovníka r. 1620. Věstník muzejního spolku. Rakovník.

- 1935: Bitva u Rakovníka 1620. Praha.

RICHTER, M.-SMETÁNKA, Z., 1975: Rozvoj středověké archeologie. In: Archeologické studijní materiály AÚ ČSAV 10/2, 62-74, 173-174. Praha.

RICHTEROVÁ, J., 1981: Německá Lhota, k. o. Kamenné Žehrovice, okr. Kladno. Historie a výzkum - Německá Lhota, eine mittelalterliche Ortswüstung, kat. Gemeinde Žehrovice, Bez. Kladno. Historie und Erforschung, AH 6, 475-479.

- 1982: Geodeticko-topografický průzkum na lokalitě Německá Lhota, okr. Kladno - Geodetisch-topografische Erkundung auf der Lokalität Německá Lhota, Bez. Kladno, AH 7, 247-252.

- 1985: Výzkum na Jungmannově nám. v Praze 1 (Předběžná zpráva) - Die Ausgrabung auf dem Jungmann-Platz, Prag 1 - Neustadt, Archaeologica Pragensia 6, 173-189.

- 1986: Nálezový soubor z vyzděné jímky na Jungmannově náměstí v Praze 1 - Ein Fundkomplex aus der Ausmauerung einer Abfallgrube am Jungmann-Platz, Prag 1, Archaeologica Pragensia 7, 205-235.

- 1997: Pražané na přelomu středověku a novověku. Život a kultura pražských měštanů v 2. polovině 15. a 16. století. Praha.

ROŽMBERSKÝ, P., 1990: Sklárna v Chotěšovičkách - The glass foundry at Chotěšovičky, Studies in PostMedieval Archaeology 1, 319-322.

SADRAVETZOVÁ, M., 2011: Archeologie zaniklé novověké šumavské vesnice Paseky (k. ú. Paseka u Borových Lad) - Archaeology of the disappeared village of modern age Paseky (cadastral area Paseka u Borových Lad), AVJČ 24, 281-298.

SEDLÁČKOVÁ, H., 2000: Sklo první poloviny 16. století na Moravě v archeologických nálezech - Mährisches Glas der 1. Hälfte des 16. Jahrhunderts in archäologischen Funden, Pravěk NŘ 10, 163-191.

- 2001: Raně renesanční sklo v Olomouci. In: Acta Universitatis Palackianae Olomucensis Facultas Philosophica, Historica 30, 195-204. Olomouc.

- 2001a: Soubor renesančního skla z areálu novokřtěneckého dvora ve Strachotíně (okr. Břeclav), JM 37, 43-68.

- 2007: From the Gothic period to the Renaissance. Glass in Moravia 1450 - circa 1560, Studies in Post-Medieval Archaeology 2, 181-226.

SEDLÁČKOVÁ, H., ed., 1998: Renesanční Olomouc v archeologických nálezech. Sklo, slavnostní keramika a kachle. Archeologické výzkumy Památkového ústavu v Olomouci 1973-1996. Olomouc.

SEDLÁČKOVÁ, H.-ROHANOVÁ, D. et al., 2016: Renaissance and Baroque Glass from the Central Danube Region. Brno.

SCHNEIDERWINKLOVÁ, P.-KOSTROUCH, F.-SƯVOVÁ, Z.-KOČÁR, P.-KOČÁROVÁ, R.-KYNCL, T.KLOZAR, A.-PETR, L., 2008: Raně novověká studna z Plzně, Perlové ulice - výpověd' archeologických a environmentálních pramenů. In: Ve službách archeologie 2. Př́rodovědné metody v archeologii a antropologii (Hašek, V.-Nekuda, R., edd.), 175-196. Brno.

SMETÁNKA, Z., 1968: Technologie výroby českých kachlů od počátku do 14. do počátku 16. století - Die Technologie der Herstellung böhmischer Kacheln vom Beginn des 14. bis zum Beginn des 16. Jahrhunderts, PA LIX, 543-578.

- 1969: K morfologii českých středověkých kachlů - Zur Morphologie der böhmischen mittelalterlichen Kacheln, PA LX, 228-265.

SMETÁNKA, Z.-ŽEGKLITZ, J., 1990: Post-mediaeval archaeology in Bohemia and its problems, Studies in Post-Medieval Archaeology 1, 7-21.

SMRŽ, Z.-HLUŠTíK, A., 2007: Polní opevnění z roku 1813 mezi Postoloprty a Budyní nad Ohří: výsledky letecké prospekce a historického bádání - Field fortifications dating from 1813 between Postoloprty and Budyně nad Ohří: results of aerial prospecting and historical research, AR L, 713-746. 
SMRŽ, Z.-MEDUNA, P.-BRU゚NA, V.-KŘIVÁNEK, R., 1999: Polní fortifikace z 18.-19. století u obce Poplze, okr. Litoměřice - Eine Feldfortifikation aus dem 18.-19. Jahrhundert bei der Gemeinde Poplze, Kreis Litoměřice, AR LI, 325-345.

SNÁŠIL, R., 1982: Zaniklé vesnice na Uherskohradišt'skobrodsku v období 13.-18. století - Ortswüstungen des 13.-18. Jh. auf dem Gebiet von Uh. Hradiště und Uh. Brod, AH 7, 163-167.

SOKOL, P., 2003: Šibenice v Bečově nad Teplou a archeologie popravišt' - The gallows at Bečov nad Teplou and the archaeology of places of execution, AR LV, 736-766.

- 2006: Šibenice v Bečově nad Teplou, hrdelní soudnictví a archeologie, Západočeský sborník historický 8 , 101-127.

- 2011: Šibenice u Přimdy, okres Tachov. Z výsledků systematického povrchového průzkumu šibeničních vrchů v západních Čechách - Galgen bei Přimda, Kreis Tachov. Aus den Ergebnissen der systematischen Oberflächenuntersuchung der Galgenberge in Westböhmen, AZČ 2, 182-188.

- 2016: Šibenice u Přimdy. Archeologický výzkum objektu se zvláštním symbolickým a sociálním významem Ein Galgen bei Přimda. Archäologische Ausgrabung eines Objektes von besonderer symbolischer und sozialer Bedeutung, AH 41, 501-524.

SOSNA, D., 2016: Heterotopias behind the fence: landfills as relational emplacements. In: Archaeologies of Waste. Encounters with the unvanted (Sosna, D.-Brunclíková, L., edd.), 162-178. Oxford - Philadelphia.

SOSNA, D.-BRUNCLÍKOVÁ, L.-HENIG, D., 2013: Testing ipad in the field: use of a relational database in garbological research, Antropologie 51/3, 421-430.

SOUKUP, M. B.-SOUKUPOVÁ, M.-ŠREJBR, A., 2012: Bohemian finds of stove tiles with the signature "HANS BERMAN", Studies in Post-Medieval Archaeology 4, 145-164.

STARÁ, M., 2007: K počátkům i výsledkům archeologického průzkumu bývalé sklárny v Bedřichově u Jablonce nad Nisou, Sborník Západočeského muzea v Plzni - Historie 18, 138-147.

STRÁNSKÁ, P., 1981: Antropologická charakteristika středověkých až novověkých pozůstatků z Vyšehradu, Archaeologica Pragensia, 321-354.

STUDIES 1990: Studies in Post-Medieval Archaeology 1 (Smetánka, Z.-Žegklitz, J., edd.). Praha.

STUDIES 2007: Studies in Post-Medieval Archaeology 2 (Žegklitz, J., ed.). Praha.

STUDIES 2009: Studies in Post-Medieval Archaeology 3 (Žegklitz, J., ed.). Praha.

STUDIES 2012: Studies in Post-Medieval Archaeology 4 (Žegklitz, J., ed.). Praha.

SŮVOVÁ, Z., 2008: Zvířecí kosti ze zaniklých vesnic. In: Hledání zmizelého. Archeologie zaniklých vesnic na Plzeňsku (Dudková, V.-Orna, J.-Vařeka, P., edd.), 25-28. Plzeň.

SƯVOVÁ, Z.-WASKOVÁ, M., 2009: Černá kočka, bílý kocour. Osteologické nálezy kočky domácí ve středověku a raném novověku z pohledu historika - Schwarze Katze, weisser Kater. Osteologische Hauskatzenfunde aus dem Mittelalter und der frühen Neuzeit und ein kleiner Exkurs über Katzen in den böhmischen Ländern in jener Zeit aus Sicht des Historikers, AH 34, 839-855.

SYMONDS, J.-VAŘEKA, P., 2014: Cowboys and Bohemians: Recreation, Resistance, and the Tramping Movement in West Bohemia, Journal of Contemporary Archaeology 1.1 (2014), 165-193.

- 2016: Paysans et soldats. Archéologie des villages de Bohême abandonnés durant la Guerre de Trente Ans. In: Violences de guerre, violences de masse (Guilaine, J.-Semelin, J., edd.), 129-145. Paris.

SYROVÁ, Z.-SYROVÝ, J., 1992: Od poslední (?) jizby k první (?) světnici (na Vysočině). In: Vesnický dům v 16. a 17. století (Škabrada, J., ed.), 111-131. Praha.

ŠEBELA, L.-VANĚK, J., 1985: Hromadný nález ze studny v areálu bratrského sboru v Ivančicích. Přelom 16. a 17. století. Ivančice.

ŠIMÁK, J. V., 1922: Ohledání ostatků Albrechta z Valdštejna a jeho př́ibuzných v Mnichově Hradišti, PA XXXIII, 153-158.

ŠÍMOVÁ, K., 2014: Černošice - rekreační lokalita Pražanů, Středočeský vlastivědný sborník 32, 30-49.

ŠIROKÝ, R., 2000: Pitná, užitná a odpadní voda v českých městech ve středověku a raném novověku. Stav a perspektivy archeologického poznání - Wasserversorgung und Wasserentsorgung in den böhmischen Städten des Mittelalters und den frühen Neuzeit. Stand und Perspektiven der archäologischen Forschung, PA XCI, $345-410$.

ŠKABRADA, J., 1977: Význam domu čp. 22 z Živohoště pro poznání vývoje obytné místnosti pozdního stř̌edověku, Sborník vlastivědných prací z Podblanicka 18, 175-203.

- 1986: Základní rysy prostorové a konstrukční struktury domu zemědělské usedlosti pozdního středověku v Čechách - Die Grundzüge der Raum- und Konstruktionsstruktur des Hauses des ländlichen Gehöfte im späten Mittelalter Böhmens, AH 11, 395-407.

- 1987: Poznámky k pokračujícímu průzkumu domu čp. 2 v Lučici (Ke vzniku středověkého domu s trojdílným půdorysem) - Bemerkungen zur forschreitenden Untersuchung des Hauses K.-Nr. 2 in Lučice, AH 12, 203-213.

- 2003: Lidové stavby. Architektura českého venkova. Praha.

ŠKABRADA, J.-DOSTÁL, P., 1984: Pozdní gotika ve vesnických usedlostech na okrese Kladno. In: Urbes medii aevi, 113-148. Praha. 
- 1985: Pozdní gotika ve vesnických usedlostech na Sedlčansku - Die Spätgotik in ländlichen Gehöften der Gegend von Sedlčany, AH 10, 481-500.

ŠKABRADA, J.-SMETÁNKA, Z., 1974: Architektura zemědělských usedlostí pozdního středověku v Čechách - Die Architektur des spätmittelalterlichen Bauernhofs in Böhmen (Ein Beitrag zur Kenntnis der materiellen Kultur des mittelalterlichen Dorfs), AR XXVI, 236-270.

ŠKABRADA, J.-SYROVÁ, Z., 1989: Dům čp. 171 v Čisté u Litomyšle, AH 14, 235-336.

ŠNEJD, D.-HANSOVÁ, J., 2008: Nález středověkého špýcharového domu v usedlosti čp. 6 v Záluží na Českokrumlovsku, Památky jižních Čech 22/1, 66-76.

ŠOLLE, M., 1990: Rotunda svatého Petra a Pavla na Budči - Die Rotunde derhl. Peter und Paul auf Budeč, PA LXXXI, 140-207.

ŠPAČEK, J., 1985: K novověké kamnářské výrobě v Čelákovicích. In: Studie a zprávy 1985, 58-66. Brandýs nad Labem - Stará Boleslav.

ŠTAJNOCHR, V., 1990: Majoliky, mezzomajoliky a polofajánse ze sbírek Národopisného oddělení Historického muzea Národního muzea v Praze, ČNM A 159, 40-86.

- 1998: I. Nové a starší nálezy střepů mezzomajolik - New and old mezzomajolica sherd finds, ASČ 2, 433-468.

- 2004: Hrnce pro tepelné zpracování pokrmů. Studia funkcí novověké keramiky - Töpfe zur Hitzbehandlung von Speisen. Studien zu den Funktionen neuzeitlicher Keramik, ASČ 8, 801-852.

- 2005: Džbány. Studia funkcí novověké keramiky - Die Krüge. Studien zu den Funktionen neuzeitlicher Keramik, ASČ 9, 729-778.

- 2006: Mísy. Studia novověké keramiky - Schüsseln. Studien zu den Funktionen neuzeitlicher Keramik, ASČ 10, 959-1046.

- 2007: Báně, transportní hrnce, spížní hrnce na ukládání tuků, konvice na náhražkovou kávu, hrnky a hrnečky. Studia funkcí novověké keramiky - Kuppelförmige Gefäße, Transporttöpfe, Speisekammertöpfe zur Fettaufbewahrung, Kannen für Ersatzkaffee, kleine Töpfe und Töpfchen. Studien zur Funktion neuzeitlicher Keramik, ASČ 11, 739-790.

- 2008: Hrnce v technologii mléka, hrnce s výpustí, speciální smetanice, hrnčířské nádoby na lůj, pístové máselnice, syrnice. Studia funkcí novověké keramiky - Töpfe in der Milchproduktion, Töpfe mit Ausguss, spezielle Sahnegefäße, Töpfermelkgefässe, Butterfässer mit Kolben, Käsebildner. Studien zur Funktion neuzeitlicher Keramik, ASČ 12, 963-1012.

ŠTAJNOCHR, V.-FRÖHLICH, J.-KRAJÍC, R.-MILITKÝ, J., 1998: II. Katalog střepových nálezů mezzomajolik - A catalogue of mezzomajolica sherd finds, ASČ 2, 445-468.

ŠULC, J.-KYPTA, J.-JEŽEK, M., 2009: K hospodaření a kultuře bydlení na středočeském statku v raném novověku: př́iklad z Trněného Újezdu (okr. Kladno) - The possibility of studying the rural housing culture between the Middle Ages and the Early Modern period on the basis of sources from Trněný Újezd (Central Bohemia), AR LXI, 697-714.

TETOUR, M., 2005: Pozdně gotická a goticko-renesanční kachlová kamna ze zámku Chanovice - Late Gothic and Gothic-Renaissance tiled stove from the Chanovice castle, AVJČ 18, 211-284.

THOMOVÁ, Z., 2004: Nález stř́ibrného prstenu s magickým nápisem v kostele sv. Prokopa ve Křtěnově - A silver ring with magic inscription found in the church of St. Prokop in Křtěnov, AVJČ 17, 261-266.

- 2005: Příspěvek k dějinám hmotné kultury novověkých Českých Budějovic - A contribution to a history of material culture of modern period of České Budějovice, AVJČ 18, 280-285.

TOMKOVÁ, K., 2005: Pohřební ritus na Pražském hradě a jeho předpolích ve středověku a novověku - charakteristika a vývoj, Castrum Pragense 7, 156-196.

TOMKOVÁ, K.-HAZLBAUER, Z., 1990: Pozdně gotické kachle z Nového Strašecí - Late Gothic stove tiles from Nové Strašecí, Studies in Post-Medieval Archaeology 1, 297-306.

TŮMA, D., 2008: Archeologie zaniklých komponent kulturní krajiny. Barokní obora Králova stolice u Dobříše Archaeology of defunct components of cultural landscape. The Baroque Králova stolice game preserve near Dobříš, ASČ $12,871-886$.

- 2010: Archeologie zaniklých komponent kulturní krajiny II. Lánská obora - Archaeology of defunct components of cultural landscape II. The Lány game park, ASČ 14, 933-954.

- 2012: Historická zařízení pro lov vlků, Památky západních Čech 2, 30-36.

TŮMA, D.-ZELINKOVÁ, V., 2011: Průzkum zanikajícího lesoparku Prašivice u Nalžovských Hor, Památky západních Čech 1, 62-76.

TYMONOVÁ, M., 2007: Kachle s lichtenštejnskými znaky ve sbírce Slezského zemského muzea - Kacheln mit liechtensteinischen Wappen in der Sammlung der Schlesischen Landesmuseums, AH 32, 501-510.

- 2012: Renesanční kachle s dvanácti biblickými hrdiny a tyrany z českého Slezska - Renaissancekacheln mit zwölf biblischen Helden und Tyrannen vom tschechischen Gebiet Schlesiens, AH 37, 679-690.

ULRYCHOVÁ, E., 2010: Dýmky z valdštejnského období z Jičína a Hořic - Pipes from the Albrecht von Wallenstein period from Jičín and Hořice, ASČ 14, 929-932.

UNGER, J., 2000: Pohřební ritus městského obyvatelstva 13.-18. století v archeologických pramenech Moravy a Slezska - Der Grabritus der städtischen Bevölkerung im 13. bis 18. Jh. in archäologischen Quellen Mährens und Schlesiens, AH 25, 335-358. 
VÁŇA, Z., 1995: Přemyslovská Budeč. Archeologický výzkum hradiště v letech 1972-1986. Praha.

VAŘEKA, J., 1973: K otázce vývoje a geografického rozšíření kamenného domu v Čechách, Český lid LX, 86-93.

VAŘEKA, J.-PETRÁŇOVÁ, L.-PLESSINGEROVÁ, A., 1986: Počátky malovaného nábytku (v českých zemích), Umění a řemesla 3, 62-64.

VAŘEKA, P., 1988: Mobiliář vesnického domu v Čechách od konce středověku do počátku národního obrození, Český lid LXXV, 202-211.

- 1989: Tehov - Tehovec, okr. Praha-východ, Výzkumy v Čechách 1986-1987, 198.

- 1992: Studium vesnického domu 16.-17. století a postmedievální archeologie. In: Vesnický dům v 16. a 17. století (Škabrada, J., ed.), 15-20. Praha.

- 2003: Keramika pozdního středověku až počátku novověku z areálu bývalých kasáren Jiřího z Poděbrad na náměstí Republiky v Praze 1 (Zjištovací výzkum v letech 1998-1999) - Ceramics of the Late Middle Ages to the Beginning of the Early Modern Period in the area of the former George of Poděbrady barracks on nám. Republiky in Prague 1 (test trenching in 1998-1999), Archaeologica Pragensia 16, 217-250.

- 2004: Výrobní (hrnčířský?) areál z časného novověku v Berouně - České ulici čp. 56, Archeologia technica, $15,78-80$.

- 2007: Archeologie novověké vesnice. In: Lidová kultura. Národopisná encyklopedie Čech, Moravy a Slezska 2 (Brouček, S.-Jeřábek, R., edd.), 32-33. Praha.

- 2008: Novověká proměna vesnice. In: Hledání zmizelého. Archeologie zaniklých vesnic na Plzeňsku (Dudková, V.-Orna, J.-Vařeka, P., edd.), 41-43. Plzeň.

- 2009: Zaniklá středověká vesnice Vojkov na Černokostelecku - svědectví archeologie - The deserted medieval village of Vojkov - the testimonial of archaeology, Kuděj 2009/1, 43-54.

- 2010: Zaniklá stř̌edověká a časně novověká vesnice Vojkov na Černokostelecku - nedestruktivní výzkum, Acta Fakulty filozofické Západočeské univerzity v Plzni 4/10, 137-171.

- 2013: Přehled kvalifikačních prací zaměřených na archeologii modernity na katedře archeologie Fakulty filozofické Západočeské Univerzity v Plzni do roku 2012. In: Archeologie Modernity. Př́stupy - metody - témata (Vařeka, P., ed.), 165-170. Plzeň.

- 2014: Zaniklá středověká a časně novověká ves Rovný na Zbirožsku (okr. Rokycany) - Das untergegangene mittelalterliche und frühneuzeitige Dorf Rovný in der Region Zbiroh (Bez. Rokycany), AZČ 7, 131-143.

- 2016: Zaniklá středověká a časně novověká ves Bukov na Zbirožsku - Das untergegangene mittelalterliche und frühneuzeitliche Dorf Bukov bei Zbiroh (Bez. Rokycany), AZČ 10, 156-167.

VAŘEKA, P., ed., 2013: Archeologie Modernity. Př́istupy - metody - témata. Plzeň.

VAŘEKA, P.-BALÝ, R.-FUNK, L.-GALUSOVÁ, L., 2008: Archeologický výzkum vesnic středověkého původu na Tachovsku zaniklých po roce 1945 - Die archäologische Grabung der nach 1945 verschwundenen Dörfer mittelalterlichen Ursprungs in der Tachauer Gegend, AH 33, 101-117.

VAŘEKA, P.-KOSTROUCH, F.-KOČÁR, P.-SƯVOVÁ, Z., 2010: Příspěvek ke studiu žijících vsí středověkého původu. Pozůstatky zástavby z pozdního středověku na parcele č.p. 121 v Mikulčicích - A contribution to research on deserted villages of Medieval origin. The remains of Late Medieval buildings on house plot no. 121 in Mikulčice, PV 51, 249-265.

VAR̆EKA, P.-SYMONDS, J., 2013: Archeologický výzkum trampské osady Alberta. In: Archeologie 19. a 20. století. Př́ístupy - metody - témata (Vařeka, P., ed.), 137-164. Plzeň.

VAŘEKA, P.-VAŘEKOVÁ, Z., 2015: Stan I perspektiwy badań archeologicznych nad reżimem komunistycznym na terenie Czech (State and perspectives of the archaeological research of the Communist totalitarianism in the Czech Republic). In: Archeologia totalitarizmu. Ślady represji 1939-1956 (Lawrynowicz, O.-Żelazko, J., edd.), 383-406. Łódź.

- 2016: Contemporary cemeteries in the district of Tachov/Tachau as evidence of population and settlement discontinuity in the 2nd half of the 20th century. In: Tod und Gedenken in der Landschaft, Siedlungsforschung. Archäologie - Geschichte - Geographie 33 (Meier, T.-Schenk, W., edd.), 225-244. Bonn.

VELÍMSKÝ, T., 1976: Archeologický výzkum historického jádra Mostu v roce 1974 - Stadtkernforschung in Brüx im Jahre 1974, AH 1, 197-204.

VITANOVSKÝ, M.-MENOUŠKOVÁ, D., 2010: Kachlové formy z Prostějova - Kostelecké ulice. K technologickým a tvůrčím otázkám vzniku renesančních kachlových reliéfů - Stove tile moulds from Kostelecká St. in Prostějov (Central Moravia). On technological and creative issues relating to the rise of Renaissance stove tile reliefs, AR LXII, 680-695.

VITULA, P., 1997: Pravěké osídlení a doklady pobytu novověkých vojsk v prostoru Rohlenky mezi Brnem a Slavkovem, VVM XLIX, 256-271.

VLČEK, E., 1976: Diagnóza zdravotního stavu Albrechta z Valdštejna stanovená na základě nejnovějšího průzkumu jeho kosterních pozůstatků, Časopis lékařství českého 115, 678.

VYŠOHLÍD, M., 2007: Finds of clay tobacco pipes from Náměstí republiky in Prague’s New Town, Studies in Post-Medieval Archaeology 2, 275-304. 
- 2009: Keramické dýmky v archeologických nálezech a jejich vypovídací možnosti - Clay tobacco pipes in the archaeological finds and their ability to testify - Clay tobacco pipes in the archaeological finds and their ability to testify, ASČ $13,965-1000$.

- 2011: Dvojdílné keramické dýmky 17.-19. století v archeologických nálezech a jejich vypovídací možnosti. In: História výroby fajok a archeologické nálezy fajok na Slovensku. Zborník príspevkov z I. medzinárodnej konferencie konanej v dňoch 29. a 30. 9. 2011 v Tekovskom múzeu v Leviciach (Dano, J.-Mihálková, N., edd.), 71-88. Levice.

- 2014: Keramické dýmky ze zaniklého židovského města v Praze-Libni - Clay tobacco pipes from the former Jewish town in Prague-Libeň - Clay tobacco pipes from the former Jewish town in Prague-Libeň, ASČ 18, 903-921.

- 2014a: Péče o zdraví v pozdním novověku v obraze archeologických pramenů. Nálezy kameninových lahví na minerální vodu - Health care in the late modern period as reflected in archaeological sources. Finds of stoneware mineral water bottles, ASČ 18, 425-454.

- 2015: Hrnčířské předměstí v Berouně: První etapa archeologického výzkumu - The Potters' suburb of Beroun: The first stage of the archaeological excavation in land parcel No. 296, ASČ 19, 411-430.

WALDHAUSER, J., 2009: Švédský vojenský tábor ze třicetileté války na katastrech Staré Boleslavi (okr. Praha-východ) a Hlavence (okr. Mladá Boleslav) - Das schwedische Militärlager aus dem Dreißigjährigen Krieg im Raum von Katastern Stará Boleslav (Bez. Prag-Ost) und Hlavenec (Bez. Mladá Boleslav), ASČ 13, 939-964.

ZAVŘEL, P., 1999: Záchranný archeologický výzkum v dolní části blažejovického systému prachatické větve Zlaté stezky - Die Rettungsausgrabung im unteren Teil des Plahetschlager Systems am Prachatizer Zweig des Goldenen Steiges, AVJČ 12, 85-97.

ZKOUMÁNí 2011: Zkoumání historických staveb. NPÚ - územní odborné pracoviště středních Čech v Praze (Razím, V.-Macek, P., edd.). Praha.

ZUMAN, F., 1931: Švédský tábor u Staré Boleslavi, Ročenka Okresní jednoty musejní v Brandýse nad Labem, $5-17$.

ŽEGKLITZ, J., 1985: Vybavení hrnčířské dílny v 15.-poč. 17. století v Čechách, MVP 23, 146-155.

- 1987: Pozdně gotické kachle se jmény hrnčírů - Spätgotische Kacheln mit Töpfernamen, AR XXXIX, 655-671.

- 1990: Topografie hrnčířských dílen a jejich podoba v 15.-poč. 17. století - The topography and outlook of pottery workshops of Prague in the 16th and incipient 17th century, Studies in Post-Medieval Archaeology 1, 215-230.

- 1990a: Příspěvek k vývoji hrnčířského kruhu v Čechách v 17.-18. století - A contribution to the development of the potter's wheel in Bohemia in the 17th-18th centuries, Studies in Post-Medieval Archaeology 1, 249-256.

- 2006: Renesanční portrétní kachle z hrnčířské dílny Adama Špačka v Truhlářské ulici v Praze - Renaissance portrait stove tiles from the pottery workshop of Adam Špaček in Truhlářská Street, Prague, AR LVIII, 78-116.

- 2007: Renaissance glassworks in Broumy, Studies in Post-Medieval Archaeology 2, 145-180.

- 2011: Tertium „Ad lupum predicantem“ - et ad Pastorem Bonum. Reformační zápasy na reliéfech českých gotických a renesančních kachlů - Tertium "Ad lupum predicantem” - et ad Pastorem Bonum. The Reformational struggle on Czech Gothic and Renaissance stove tile reliefs, AR LXIII, 644-655.

- 2012: Grafické a další předlohy motivů na kachlích z českého prostředí. Renesanční kachle jako prostředek šíření idejí a kultury doby reformace - Prints and other artwork models for motifs on stove tiles in Bohemia. Renaissance stove tiles as an agent in the spread of Reformation ideas and culture, AR LXIV, 265-319.

- 2013: Archaeology of the Modern Period in the Czech Territories: A Long Tradition and Long Beginnings. In: Historical Archaeology in Central Europe (Mehler, N., ed.), 53-68. Rockville.

- 2014: Reformační kamna ze Špýru, Egerberku a Prahy - Reformational tiled stoves from Speyer, Egerberk and Prague, AR LXVI, 515-547.

ŽEGKLITZ, J.-HAZLBAUER, Z.-CHOTĚBOR, P., 1992: Pokus o rekonstrukci kachlových kamen ze zaniklé renesanční sklárny v Broumech - Versuch einer Rekonstruktion des Kachelofens aus der Renaissanceglasshütte in Broumy, AR XLIV, 94-108.

ŽEGKLITZ, J.-SMETÁNKA, Z., 1989: Historie a postmedievální archeologie, ČsČH 37, 728-738.

ŽEGKLITZ, J.-VITANOVSKÝ, M.-ZAVŘEL, J., 2009: Soubor kachlových forem z pražské hrnčířské dílny Adama Špačka a její kachlová produkce v letech 1531-1572 - An assemblage of stove tile moulds from the Prague pottery workshop of Adam Špaček and the tile production of this facility in the years 1531-1572, AR LXI, 427-466.

ŽEGKLITZ, J.-ZAVŘEL, J., 1990: Geochemical and petrographical studies of the post-medieval pottery of the Prague and Beroun regions. On the question s of raw materiál sources and provenance, Studies in PostMedieval Archaeology 1, 95-126.

- 2004: Nové nálezy kamnářských výrobků s portrétem Jana Husa. Př́íspěvek k poznání výroby českých renesančních kachlů - New finds of stove-makers' wares bearing a portrait of Jan Hus. A contribution to an understanding of Czech Renaissance stove tile production, AR LVI, 591-618. 


\section{Archeologie novověku v České republice}

\section{1 Úvod}

K nejdynamičtěji se rozvíjejícím subdisciplínám oboru se dnes bezesporu řadí archeologie zaměřená na naši nejmladší minulost, jejíž zkoumání archeologickými metodami si ještě nedávno historické bádání stěží dokázalo představit. V souladu s historickým členěním vymezujeme chronologický rámec archeologie novověku (někdy označované jako postmedievální archeologie) 16.-18. stoletím, archeologii moderní doby pak 19.-20. stoletím, ovšem spodní hranice někdy samostatně vyčleňované archeologie současnosti kolísá (k chronologii srov. Smetánka-Žegklitz 1990, 7; Vařeka 2013, 8-9). V České republice se přes pokusy o vyčlenění archeologie novověku nepodařilo dosud vytvořit jednotnou platformu mající charakter specializovaného periodika, pravidelných konferencí nebo badatelského centra/center. Je samozřejmě otázkou, zda je vydělení takto orientované kooperace a koordinace na celostátní úrovni potřebné, či zda jsou postačující jiné, již existující informační a výzkumné rámce a sítě. Přehled dosavadního vývoje archeologického výzkumu nejmladší minulosti v českých zemích podává tento př́íspěvek.

\section{Počátky zájmu o novověké artefakty}

Obdobně jako v případě archeologie jako takové jsou i počátky zájmu o hmotnou kulturu novověku v Čechách a na Moravě spojeny s vytvářením soukromých i muzejních sbírek na sklonku 19. a v první polovině 20. století. Vedle v podstatě náhodného sběru artefaktů, posuzovaných z hlediska dějin umění a uměleckého řemesla, byly již od počátku systematicky získávány také nálezy z archeologických situací, byt' dokumentaci jejich nálezového kontextu ještě nebyla věnována velká pozornost. Výjimečné postavení mají sbírky novověkých nálezů Muzea hlavního města Prahy a Pražského hradu. Profesor Českého vysokého učení technického J. Koula zachraňoval soubory novověké keramiky při rozsáhlých zemních pracích v souvislosti s radikální přestavbou několika částí pražského historického jádra a jeho dodnes využívané publikace Co nám vyprávěji pražské střepy se řadí k prvním studiím o novověké keramice v evropském kontextu založeným na archeologických nálezech (Koula 1917; 1918; 1919). Sbírka novověkých artefaktů získaná při stavebních pracích na Pražském hradě, kterou založil architekt a stavitel K. Fiala, byla soustavně rozšiřována o hodnotné soubory keramiky a skla z novověkých odpadních jímek zkoumaných pod vedením I. Borkovského, K. Gutha a J. Pasternaka již od roku 1925 (Blažková-Vepřeková 2015, 15). Z prvních muzejních archeologů náleží, s ohledem na záměrné získávání novověkých artefaktů cílenými výkopy (především keramiky), výjimečné místo K. Čermákovi, zakladateli archeologických sbírek muzea v Č́alavi (Čermák 1896; 1906; 1914; 1914a). Zatímco v Čechách můžeme v zájmu o novověkou hmotnou kulturu hledat vliv kulturní historie a dějin umění, resp. uměleckého řemesla, na Moravě se výrazně projevuje zaměření na lidovou kulturu a umění, především lidovou hrnčinu. Keramik a keramolog H. Landsfeld, který působil na jižní Moravě a na jihozápadním Slovensku, ve své době zcela ojediněle propojil přístup etnografický a archeologický. Od roku 1932 realizoval celou řadu odkryvů zaměřených na časně novověká výrobní centra habánské, později i další tradiční keramiky, které měly odhalit kořeny lidového rukodělného hrnčířství (Landsfeld 1947; 1950; 1953; 1971). Studium moravské lidové keramiky, včetně habánských fajánsí, rozvíjel také historik umění a keramolog K. Černohorský (1928; 1928a; 1931; 1941).

Již v první polovině 20. století přitahovaly pozornost archeologické památky spojené s třicetiletou válkou. Archivář J. Renner dokumentoval polní opevnění spojená s bitvou u Rakovníka z roku 1620 (Renner 1912; 1935), obdobně byla věnována pozornost švédskému polnímu táboru u Mladé Boleslavi (Zuman 1931) a ve 20.-30. letech se objevují též první antropologické studie zaměřené na kosterní pozůstatky Albrechta z Valdštejna (Matiegka-Malý-Bergl 1934; Šimák 1922).

\section{Archeologie novověku od 50. do 80. let}

Ve druhé polovině 20. století se v českých zemích začala intenzivně rozvíjet archeologie středověku, která rozšířila původní chronologický rámec - omezený na ,slovanské“ období - také do vrcholného a pozdního středověku (např. Richter-Smetánka 1975). Za významný krok ve vymezení historické archeologie je považována přednáška historika umění a tehdejšího ředitele Národního muzea V. Denksteina roku 1953, který jako její horní chronologickou hranici chápal dnešek (Denkstein 1953, 200-221; Smetánka-Žegklitz 1990, 10). Je však třeba konstatovat, že tato nadčasová vize sahající až k dnešní archeologii moderní doby a současnosti zcela zapadla. Vždyt' ještě dlouho do druhé poloviny 20. století, kdy se postupně tzv. 
historická archeologie konstituovala, byly terénní situace a artefakty z novověku a nezřídka i ze sklonku středověku vnímány jako jakýsi „druhotný produkt“ archeologického odkryvu, který nebyl až na výjimky odborně hodnocen a zpracováván.

$\mathrm{V}$ době, kdy se teprve začínal ve větším měřítku rozvíjet výzkum památek $\mathrm{z}$ mladšího středověku, byl v letech 1956-1971 východně od Brna realizován rozsáhlý odkryv tvrze v Kralicích nad Oslavou, který odhalil hmotné památky spojené s tajným českobratrským sídlem a tiskárnou pracující v poslední čtvrtině 16. a první čtvrtině 17. století. S výzkumem je spojeno jméno V. Fialové, která patřila k zakladatelské generaci archeologů středověku a zároveň se řadí k průkopníkům archeologie postmedieválního období v tehdejším Československu (Fialová 1956; 1957; 1958). Z Moravy pochází také jeden z prvních vyhodnocených a publikovaných souborů časně novověké keramiky a skla, který byl získán při záchranném archeologickém výzkumu odpadní jímky, a to v Brně - Orlí ulici roku 1957, provedeném B. Novotným (1959). Soubor, který „ukazuje na pestrý obraz keramické a sklářské výroby“, byl datován do „doby, kdy se vemi uchopili moci Habsburkové“, a považován za materiálový pramen „ke studiu nejstaršich dějin Moravy“ (Novotný 1959, $3,19,23)$. Nedlouho po výzkumu B. Novotného v Brně realizoval B. Nechvátal ve Struhách u Benátek nad Jizerou v roce 1960 zřejmě první záchranný archeologický výzkum v intravilánu vsi, jehož význam pro studium hmotné kultury novověké vesnice byl rozpoznán (Nechvátal 1966). Spáleništní situace poskytla kromě keramického souboru, ,který je nálezovým celkem z vesnického prostředi“ (tamtéž, 207), navíc zuhelnatělé botanické makrozbytky, analyzované Z. Tempírem (tamtéž, 206). Jedná se tak patrně o první případ, kdy byl do výzkumu novověké situace zapojen př́istup odkazující k budoucí environmentální nebo biologické archeologii. Další publikované soubory novověkých nálezů jsou spojeny s menšími záchrannými akcemi v historickém jádru Prahy (Frauenterka 1958; Liška 1958; Mašek 1966). V 60. letech se začalo rozvíjet studium novověké hrnčiny a kachlů archeologickými metodami, které se zaměřilo především na typologickou klasifikaci a chronologii movitých artefaktů, představujících nejpočetnější složku nálezových souborů (Nechvátal 1968; Smetánka 1968; 1969).

V 70. a 80. letech se archeologie novověku rozvíjela především v návaznosti na rostoucí počet záchranných archeologických výzkumů, které přirozeně odhalovaly také novověké památky. V souvislosti se stavebními aktivitami bylo nejvíce pozornosti věnováno ohroženým terénním situacím v jádrech českých i moravských měst, které zahrnovaly jak menší zásahy do historických souvrství, zkoumání výplní jímek a studní, tak také rozsáhlé odkryvy celých městských parcel (kombinované ve stále spíše ojedinělých případech se stavebně historickým průzkumem) nebo i dokumentaci vývoje veřejných prostranství, fortifikací a různých městských zařízení (např. Frýda 1979; Bláha 1983; Drda 1980; Himmelová-Procházka 1990; Huml 1971; 1975; 1979; 1989; Charvátová-Charvát 1981; Klápště-Muk 1988; Měřínský 1979; Michna 1977; Richterová 1985; 1986; Šebela-Vaněk 1985; Velímský 1976). Prvních antropologických rozborů se dočkaly kosterní pozůstatky z novověkých hřbitovů (např. Fetter 1970; Hanáková-Martinec-Vyhnánek 1975; Hanáková-Stloukal 1988; Stránská 1981), ale také slavných osobností (Albrecht z Valdštejna - Vlček 1976).

Zvláštní postavení nadále patřilo novověkým situacím a nálezovým souborům z Pražského hradu, které byly předmětem pokračujících předstihových výzkumů, z nichž některé byly již v této době publikovány (Boháčová-Frolík-Petříčková-Žegklitz 1990; Boháčová-Frolík-Tomková-Žegklitz 1988; BoháčováFrolík-Žegklitz 1989; Borkovský 1975). Odkryvy tvrzí a hradů registrovaly v případě jejich kontinuálního vývoje do novověku také jejich nejmladší fáze, ovšem vyhodnocení se tato zjištění až na stručné zmínky nedočkala, stejně jako výzkumy klášterů.

V daleko méně početných př́ípadech byly záchrannými výzkumy dokumentovány narušené archeologické terény z novověku ve vesnickém prostředí (Burian 1975; Huml 1982; Kundera-Měřínský 1987), ovšem setkáme se i s cílenými odkryvy částí vesnického jádra, byt' v rámci systematického výzkumu předhradí libického hradiště (Justová 1981; 1985; 2002). První soustavný archeologický výzkum zaměřený na ves zaniklou v časném novověku byl realizován J. Richterovou a Z. Smetánkou na lokalitě Německá Lhota (k. ú. Kamenné Žehrovice) na Kladensku v letech 1970-1971. Jednalo se o průkopnický projekt, který komparoval výpověd' archeologických a písemných pramenů a jako první vyzdvihl možnosti a význam takto orientovaného výzkumu pro poznání novověké vesnice (Richterová 1981; 1982). V souvislosti se zájmem o zaniklé středověké vesnice byly dokumentovány také další lokality, zaniklé v 16. až v první polovině 17. století (např. Fröhlich 1986; 1990; Snášil 1982; Vařeka 1989). Poprvé byly v této době vyhodnoceny také odkryvy venkovských pohřebišt', které sloužily až do novověku, byt' jejich výzkum sledoval primárně odlišné cíle (Budeč - Šolle 1990; Váňa 1995; Oškobrh - Blajerová 1974; Hrdlička-Richter 1974). V evropském kontextu byla ojedinělá pozornost věnována zaniklému novověkému vysokohorskému osídlení v Krkonoších (Bartoš 1976; Kalferst-Sigl 1990; Lokvenc-Bartoš-Švec 1973).

Velký význam pro archeologii vesnického prostředí mělo rozpoznání nejstarší vrstvy dochované vesnické architektury ze samého sklonku středověku a počátku novověku stavebně-historickými výzkumy, a to jak zděné z kamene, tak i dřevěné, roubené konstrukce (Škabrada 1977; 1986; 1987; Škabrada-Dostál 
1984; 1985; Škabrada-Smetánka 1974; Škabrada-Syrová 1989; Vařeka 1973). Archeologie tak získala jedinečný srovnávací materiál pro interpretaci vlastních pramenů a zároveň zásadním způsobem rozšířila možnosti poznání časně novověké vesnice, zejména ve spolupráci s rozvíjející se historickou etnografií (např̀. Frolec 1980; Petráňová-Vařeka 1987; Vařeka-Petráňová-Plessingerová 1986; 1988).

V 70. a 80. letech byly položeny základy dlouhodobého výzkumu českých skláren, a to nejen vrcholně a pozdně středověkých, ale také sklářských hutí z 16.-19. století (Fröhlich 1989; Hejdová 1981; Kavan 1982; Rožmberský 1990). Pozornost byla věnována také dalším novověkým zpracovatelským a výrobním aktivitám (srov. sborníky Archeologia technica pod redakcí J. Merty). V Jáchymově se podařilo s využitím archeologických a stavebně historických metod prozkoumat unikátně zachované pozůstatky mincovny z 16. století (Muk-Hus 1985).

V 80. letech se archeologie poprvé zaměřila na polní opevnění ze 17. a 18. století představující hmotné pozůstatky početných vojenských tažení, která opakovaně procházela českými zeměmi v tomto období (Matoušek-Hájek-Kubů-Meduna 1990; Hájek-Kubů-Matoušek 1992; Kubů-Zavřel 1988; Meduna 1990). Vedle toho je třeba připomenout archeologickou dokumentaci náhodných nálezů masových hrobů na bojišti na Bílé hoře v Praze (Havel 1980; Janská 1966).

Terénní archeologické výzkumy přinášely obrovské soubory novověkých nálezů, které se již v této době v některých případech stávaly předmětem rozborů. Zájem se přirozeně obracel $\mathrm{k}$ nejpočetnější kuchyňské a stolní keramice (např. Budinská 1976; Frolík-Sigl 1990; Charvátová-Charvát 1981; KunderaMěřínský 1987; Matoušek-Scheufler 1980; 1983; Matoušek-Scheufler-Štajnochr 1985), postupně se rozvíjelo také studium kachlů (např. Boháčová 1990; Hazlbauer 1988; 1990; Hazlbauer-Špaček 1986; Špaček 1985; Tomková-Hazlbauer 1990; Žegklitz 1987) a ojediněle dalších druhů artefaktů (např. Beranová 1989; Durdík 1990). Pozornost byla věnována také širši problematice novověkého hrnčířského řemesla, hrnčířských dílen a hrnčíru s využitím písemných, ikonografických a hmotných pramenů (Žegklitz 1985; 1990; 1990a). Na sklonku 80. let se již setkáváme s interdisciplinárním výzkumem keramiky s využitím geochemických a petrografických metod, který otevřel nové perspektivy studiu novověkých hrnčířských technologií, vymezení skupin hrnčiřského zboží a jejich provenience (Žegklitz-Zavřel 1990).

Jistě není náhodou, že na Moravě byla nadále rozvíjena tematika novokřtěnců a jejich vynikajících keramických výrobků. Již od 70 . let 20 . století prováděl etnograf a archeolog J. Pajer nové terénní výzkumy a analyzoval soubory habánské, ale i jiné novověké keramiky z celé řady moravských lokalit (Pajer 1974, 169-184; 1982; 1983; 1990). Kromě klasifikace, typologie, chronologie i funkční interpretace novověkého keramického zboží se zaměřil i na teoretické otázky spojené se zaměřením archeologie novověkého období. Zabýval se nejen terminologií, např. „lidové“ či „,novověké“ keramiky, ale i úvahami o vymezení nové subdisciplíny označované jako „novověká archeologie“ (Pajer 1983, 7-9) či o použivání termínu „industriální archeologie“, spojeného s okruhem badatelů kolem J. Merty, který navrhoval pro archeologii novověkého období termín „průmyslová archeologie“ (Merta 1980, 5-8).

V roce 1982 byla v Brně pod záštitou Československé společnosti archeologické (ČSSA) založena Pracovni skupina pro archeologii 16.-19. století, která se zaměřila na oborovou terminologii, klasifikaci lokalit a nálezového fondu, prričemž členové se měli soustředit na získávání pramenné základny ve vymezených tematických okruzích a konkrétních regionech (Pajer 1983, 154, pozn. 15). V roce 1986 se v Okresním muzeu v Berouně konalo pracovní setkání archeologů, kteří se v rámci svého odborného zájmu zabývali zkoumáním lokalit a artefaktů z novověkého období. Završením úsilí na tomto poli se stal sborník Studies in Post-Medieval Archeology 1, připravovaný koncem 80. let a vydaný Archeologickým ústavem ČSAV v Praze v roce 1990 pod redakcí Z. Smetánky a J. Žegklitze (Studies 1990). Úvodní prŕíspěvek editorů shrnoval dosavadní vývoj postmedievální archeologie, její témata, problémy a perspektivy na našem území s mezinárodním přesahem a stal se určitým programovým prohlášením této archeologické subdisciplíny (Smetánka-Žegklitz 1990, 7-21). Základy předznamenávající další rozvoj české postmedievální archeologie tak byly položeny, byly načrtnuty její cíle a byl vymezen chronologický rámec (Žegklitz 2013, 57; též Matoušek 1991). Pojetí této archeologické specializace korelovalo se studiem hmotné kultury v rámci historických věd využívajícím širokého spektra pramenů, které v 80.-90. letech vyvrcholilo vydáním čtyřsvazkové syntézy dějin stř̌edověké a novověké hmotné kultury pod redakcí J. Petráně. ${ }^{1}$

\section{Rozvoj archeologie novověku od roku 1990}

Podíváme-li se na období uplynulé od vydání prvního sborníku věnovaného české postmedievální archeologii, můžeme konstatovat kontinuitu hlavních směrů výzkumu zahájených v předchozím období,

\footnotetext{
1 Petráň 1985; 1995; 1997. Srov. Krajíc 2007, 138. Formování archeologie novověku v českých zemí nachází mnoho společných rysů s vývojem v dalších středoevropských zemích (srov. Courtney 2009; Mehler 2013). Již dříve se ovšem postmedievální archeologie etablovala a intenzivně rozvíjela ve Velké Británii. Society for Post-Medieval Archaeology (http://www.spma.org.uk/) vydává od roku 1966 časopis Post-Medieval Archaeology (http://www.tandfonline.com/loi/ypma20). K vývoji do 80. let srov. např. Crossley 1990.
} 
rozšíření a prohloubení studia již dříve sledovaných témat, ovšem i prosazení nových směrů bádání. Nejenže se výrazně navýšilo množství archeologických pramenů z postmedieválního období, ale vzrostla také jejich kvalita a výpovědní možnosti, a to díky rozvoji metod terénního výzkumu, analýz artefaktů a ekofaktů a stále se rozšiřující spolupráci s dalšími vědními obory. ${ }^{2}$

V důsledku rozsáhlých společenských a hospodářských změn došlo od počátku 90. let k nebývalému stavebnímu rozvoji. Výstavba v intravilánech obcí i na jejich periferiích - zahrnující průmyslové zóny, skladovací areály, výstavbu celých nových obytných čtvrtí, komplexy nákupních center, inženýrské sítě, rekonstrukce a přestavbu historické zástavby či výstavbu nových objektů - nevratně proměňuje podobu sídel i historické krajiny. Tyto stavební zásahy si vyžádaly nejen zvýšenou potřebu archeologických terénních aktivit, ale i proměnu struktury archeologické památkové péče a metod její práce. Jednak se zahustila sít' odborných pracovišt’ zaměstnávajících archeology, a také vznikly i instituce nové, zaměřené dominantně na výkon terénní složky archeologické památkové péče. Mimořádný nárůst terénních výzkumů se přirozeně odrazil v rostoucím množství zkoumaných novověkých archeologických situací, což na jedné straně nabídlo možnost významně rozšířit poznání tohoto období archeologickými metodami, ovšem na druhé straně se zvýšily nároky na archeologická pracoviště, která se až na výjimky dříve tímto obdobím soustavně nezabývala. Archeologie novověku se v uplynulém čtvrtstoletí již stala neodmyslitelnou součástí terénních výzkumů ohrožených lokalit a zároveň se zintenzivnila mezioborová spolupráce.

Na berounský seminář navázal se značným časovým odstupem další pokus o vytvoření platformy zaměřené na archeologii novověku, a to setkání organizované B. Dragounem v Muzeu Orlických hor v Opočně v roce 1999. Pořádat pravidelná odborná setkávání zájemců o archeologii novověku se podařilo až společnosti Archaia Praha, o. p. s., v letech 2006-2014, kdy byly ve dvouletých odstupech pořádány konference Forum Archaeologiae Post-mediaevalis, které záhy získaly mezinárodní rozměr. Z nich dosud vzešly tři sborníky, jež osobou editora (J. Žegklitz), názvem Studies in Post-Medieval Archaeology a pořadovými čísly 2-4 navazují na první sborník téhož názvu.

Publikace zaměřené na archeologii novověku nacházejí své místo stále častěji v centrálních archeologických periodikách i v regionálních časopisech. Postmedieválnímu období je pochopitelně nejblíže archeologické bádání zaměřené na pozdní středověk, a proto dochází k výzkumnému překrývání a prolínání. Studie zaměřené primárně na archeologii mladšího středověku často zahrnují i období chronologicky následné a naopak, což odráží historický vývoj většiny lokalit i provázanost výzkumných témat. Archeologické studie věnované postmedieválnímu období tak obsahují i sborníky a časopisy zaměřené primárně na archeologii středověku (Archaeologia historica, Castellologica bohemica, Castrum Pragense, Forum urbes medii aevi, Mediaevalia archaeologica).

Stále více se propojuje archeologický a stavebně historický výzkum staveb ze středověku a novověku (srov. např. Zkoumání 2011, zvl. 63-67), což umožňuje kombinovat a koordinovat nové přístupy k záchraně a ochraně této části kulturně historického dědictví. Projevem takové spolupráce jsou konference věnované problematice stavebně historického průzkumu, zahájené v roce 2002 zasedáním v Zahrádkách u České Lípy a organizované Sdružením pro stavebně historický průzkum (sborníky Svorník), a konference Dějiny staveb pořádané od roku 2000 Klubem Augusta Sedláčka v Nečtinách u Plzně a nově v nedalekém Centru stavitelského dědictví Národního technického muzea v Plasích (stejnojmenné sborníky Dějiny staveb).

Archeologické studium novověkého období si již nelze představit bez úzké spolupráce s mnoha dalšími vědními obory, které se podílejí na nedestruktivním i destruktivním terénním výzkumu, při vyhodnocení terénních situací, analýzách nálezového fondu i na celkové syntéze a interpretaci. Kromě tradiční spolupráce s historickými vědami se především zvyšuje podíl přírodovědných a technických disciplín. Na počátku tohoto století sehrálo významnou roli pravidelné setkávání archeologů s odborníky z dalších vědních oborů na konferencích Př́rodovédné metody v archeologii a antropologii, kde se na kvalitativně nových základech rozvíjela spolupráce archeologů, př́írodovědců, lékařů, techniků, technologů ad. Přehled o okruzích společných badatelských zájmů, které zahrnovaly také témata z novověku, podává sedm svazků sborníku Ve službách archeologie.

Významným tematickým okruhem postmedievální archeologie je výzkum výrobních zařizení a studium historických technologií. Zásluhou J. Merty z Technického muzea v Brně jsou každoročně pořádány na celostátní úrovni semináře Zkoumáni výrobnich objektů a technologii archeologickými metodami, jejichž publikačním výstupem je série obdobně nazvaných sborníků, známých jako Archeologia technica. Z novověkých objektů zde byla věnována pozornost výzkumům pekařských pecí, vápenek, skláren, cihelen, hamrů, železářských a kovoliteckých zařízení. Prezentovány jsou i výsledky rozborů surovin, hotových výrobků ze železa, barevných a drahých kovů, polotovarů, odpadů apod.

2 K metodám terénních výzkumů srov. napr. Gojda 1997; Gojda-John a kol., 2013; Kuna a kol. 2004; Kuna-Vařeka 2007; Procházka-Vařeka 2005). Počítačovým metodám je věnována série konferencí Počítačová podpora v archeologii. Ke spolupráci s př́rodními vědami srov. např. časopis IANSA (www.iansa.eu.). 
Přehled by nebyl úplný, pokud bychom nepřipomněli periodika a sborníky, v nichž vycházejí studie věnované tomuto období blízkými vědními obory a objevují se také archeologické příspěvky (zejm. Časopis přátel starožitností / Muzejni a vlastivědná práce, Pri̊zkumy památek, Zprávy památkové péče).

Z výzkumných témat sledovaných po roce 1989 se pokusíme shrnout ty nejvýznamnější. Ke značnému posunu došlo ve výzkumu novověké vesnice. Menší přehledové práce se zaměřily na stav bádání, možnosti archeologického výzkumu vesnického prostředí novověku a poznání tradiční architektury z hlediska archeologie (Vařeka 1992; 2007; 2008). Komparativní výzkum, využívající různých druhů pramenů, ukázal možnosti studia vývoje kulturní krajiny, struktury sídel a plužiny (Klír-Beránek 2012; Dohnal 2003; 2003a; 2008; Klír 2008) a pozornost byla věnována i reliktům pozemkových hranic (Bayer-Beneš 2004; Beneš-Hrubý-Michálek-Parkman 1999; Dohnal-Šída 2007). Reakcí na rostoucí potřebu záchranných akcí v jádrech vsí a rozpoznání jejich potenciálu byla formulace výzkumného programu archeologického studia existujících vsí středověkého původu (Nováček-Vařeka 1996; 1997). Několik publikovaných případů ukazuje, že archeologie poskytuje nenahraditelné prameny pro poznání proměn novověké vesnice, a to v měřítku celých sídel i v mikroúrovni jednotlivých parcel a jejich zástavby (Dohnal-Vařeka 1997; Dohnal-Korený-Koucký-Procházka-Šamata 2001; Gabriel 1994; Meduna-Kypta-Šulc-Matějek 2001; Militký-Vařeka 1997; Nováček 1997; Nováček-Vařeka 1994; Vařeka-Kostrouch-Kočár-Sůvová 2010). Významně se rozšírila skupina nejstarších identifikovaných vesnických staveb z předbělohorského období, zejména zděných objektů a dendrochronologické datování částí roubených domů posunulo jejich spodní hranici dochování až na samý sklonek středověku (např. Anderle-Ježek-Zavřel 2000; Berková 1999; Foud-Karel 1998; KovářKypta-Šulc 2014; Kypta-Pešta-Šulc-Veselý 2008; Kypta-Šulc 2003; 2004; 2005; 2007; Kypta-Šulc-Veselý 2005; Krásný-Kypta-Šulc 2005; Syrová-Syrový 1992; Škabrada 2003; Šnejd-Hansová 2008). Výzkum zaniklých vsí se stále častěji zaměřuje také na novověké poustky, především sídla opuštěná v době třicetileté války (Symonds-Vařeka 2016; Vařeka 2009; 2010; 2014; 2015). Dále byla pozornost věnována naprríklad ovčínům (Čapek-Preusz 2012) nebo mlýnům (Beránek-Doležal-Korený-Křivánek-Vařeka 1998; Galusová 2007; Galusová-Funk 2011) a na starší aktivity navázalo studium novověkého budního hospodaření ve vrcholových partiích Krkonoš (Hartmanová 2005). Novým archeologickým tématem se staly vesnice středověkého a novověkého původu zaniklé po roce 1945, jejichž pozůstatky byly v posledních letech dokumentovány zejména v jižních a západních Čechách (např. Bureš 2015; Funk 2010; Galusová 2007; 2010; Matoušek-Holý 2007; Sadravetzová 2011; Vařeka-Balý-Funk-Galusová 2008).

Největší objem předstihových a záchranných akcí byl vzhledem ke koncentraci stavebních aktivit realizován v městském prostředí. Pouze velmi malá část výsledků výzkumů byla podrobněji publikována, přičemž sledované otázky zahrnovaly kromě vývoje parcel, městského domu a jeho zázemí, řemeslných provozů a hmotné kultury také zdroje vody, odpady nebo fortifikace (např. Beneš 1996; Bláha 1998; Černoš-Hejhal 2012; Dohnal 2006; Ernée 2001; Juřina-Kašák-Samojská 2007; Juřina a kol., 2005; Krajíc 1998; 2006; 2009; Merta-Peška 2009; Motyková-Sedláčková 1996; Motyková-Šenberger 2000; OrnaDudková 2016; Richterová 1997; Sedláčková 1998; Široký 2000; Vařeka 2004; Vyšohlíd 2015). Předmětem předstihových archeologických výzkumů se staly také novověké městské hřbitovy (např. Čiháčková-Omel-

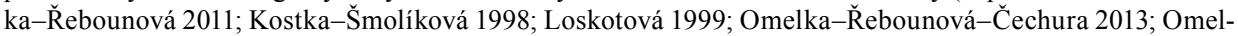
ka-Řebounová-Šlancarová 2009; Unger 2000; více k hrobové výbavě níže) a v Praze byly vyhodnoceny výzkumy novověkých pohřebních areálů na Pražském hradě (Blažková-Dubská 2005; 2005a; Tomková 2005). V několika případech byly představeny výsledky předstihových odkryvů klášterů a jejich hřbitovů (Flek-Kubálek-Omelka-Podliska 2009; Juřina-Vyšohlíd 2009; též jezuitská kolej - Frolík 2007; 2013; 2014) nebo záchranných výzkumů židovských sakrálních objektů (Frolík-Pecinovská-Vepřeková 2015; Kalferst 1994). Poměrně malá pozornost se dosud věnovala zhodnocení archeologických výzkumů novověkých vrchnostenských sídel (např. Foster 2009; Hůrková a kol. 2015), jejichž poznání je nadále doménou stavebně historického výzkumu. Značný zájem archeologie v posledních letech přitahují místa spojená s výkonem hrdelního soudnictví (Fröhlich 2006; Kovář 2009; Likovský-Velemínský 2006; Mašková-Michálek 2006; Michálek 2006; Sokol 2003; 2006; 2011; 2016).

Významně se rozšiřilo poznání lokalit a areálů spojených s novověkými válečnými konflikty, především bojišt', obležení a polních fortifikací, a to s využitím archeologických, obrazových a mapových pramenů (souhrnně Blažková-Matoušek 2010; Grabolle-Matoušek-Meduna-Smrž 2009; Matoušek 2011a; 2012; 2015a; Matoušek-Blažková 2012; k jednotlivým lokalitám např. Altová-Kössl-Matoušek-Procházka-Šimek 2008; Beneš-Kubů-Török 1995; Blažková 2011; Fröhlich 2000; Kovárník-Horáčková-Vargová-Mucha-Vachunková 2006; Loskotová-Hanák 1995/1996; Matoušek 2006; Matoušek-Kovandová 2005; SmržHluštík 2007; Smrž-Meduna-Brůna-Křivánek 1999; Vitula 1997; Walhauser 2009). Na starší badatelské tradice navazuje zkoumání skláren (Fröhlich 1993; 1994; 1994a; 1995; 1995a; 1996; 2015; Frýda 2014; Hrubý-Hejhal-Kašák-Malý-Valkony 2009; Stará 2007; Žegklitz 2007; Žegklitz-Hazlbauer-Chotěbor 1992; srov. též sborníky Historické sklo) a dalších lokalit spojených s výrobními a zpracovatelskými činnostmi 
(např. Bláha-Sigl 2007; Dragoun-Matoušek 2004; Dragoun-Matoušek-Woitsch 2006; Kovář 2014; srov. též sborníky Archeologia technica). Slibně se rozvíjí montánní archeologie novověkých těžebních areálů s využitím nových metod dálkového průzkumu i terénního výzkumu (např. Malina 2014; 2015; 2016; Malina-Karel 2012; Malina-Urban 2013; k montánní archeologii srov. též sborníky věnované dějinám hornictví a důlních prací Stříbrná Jihlava). Archeologie přináší nové poznatky o zaniklých komunikacích (např. Hlásek-Gersdorfová-Hrušková-Plzák-Pták-Stehlíková 2014; Kubů-Zavřel 2007; Zavřel 1999), včetně hmotných pozůstatků moderních dopravních systémů (koněspřežná dráha - srov. Hajn-Chvojka-Majer 2004; Chvojka-Menšík 2013). Ukazuje se, že archeologie dokáže odhalit relikty specifických součástí kulturní krajiny novověku, jako byly obory, lesoparky nebo zařízení sloužící k lovu, a významně tak přispět k poznání jejich původní podoby (Preusz-Paclíková-Pták 2013; Tůma 2008; 2010; 2012; Tůma-Zelinková 2011). Teprve postupně se prosazují archeologické metody při výzkumu novověkých zahrad (Gojda-Hladký-Janál-Jančo-Milo-Lisá-Petř́ík-Prokeš 2015).

Z movitých artefaktů byly nadále nejčastěji analyzovány soubory kuchyňské a stolní keramiky a postupně se rozšiřuje poznání technologie, morfologie a výzdobných technik, začínají se vymezovat jednotlivé skupiny hrnčířského zboží, jejich výrobní okruhy, provenience a propracovávat chronologie (např. Blažková 2013; Blažková-Dubská 2007; 2009; Blažková-Frolík-Žegklitzová 2012; Cvrková 2001; Čapek-Preusz 2016; Dohnal-Fröhlich 2000; Dohnal-Vařeka 2002; Chybová-Válka 1994; Malík-Peška 1994; Preusz 2013; Vařeka 2003). Zvláštní pozornost byla věnována keramice vysokého ohně (Pajer 1996; 2001; 2001a; 2007; Štajnochr 1990; 1998; Štajnochr-Fröhlich-Krajíc-Militký 1998; Vyšohlíd 2014a) a pro interpretaci archeologických dat mají velký význam etnologické studie o lidové hrnčině (Štajnochr 2004; 2005; 2006; 2007; 2008). Mimořádně se rozrostla literatura o pozdně gotických a renesančních kachlích, která zahrnuje soupisové a katalogové práce (Brych 2004; Brych-Stehlíková-Žegklitz 1990; Fröhlich-Pavlík 2014; 2015; Krasnokutská 2005; Menoušková-Měřínský 2008; Orna 2005; Pavlík-Vitanovský 2004), rozbory souborů z prostředí vesnic (Dreslerová-Kypta-Šulc 2004; Fröhlich-Kypta 2010; Korený-Kypta-Šulc 2003; Kypta-Šulc 2006; Šulc-Kypta-Ježek 2009), měst (např. Drobný-Sedláčková 1997; Čapek 2016; Holub-Jordánková-Loskotová 2009; Kováčik-Veselá 2009), panovnických a šlechtických sídel (Brych 2001; Durdík-Hazlbauer 1991; Durdík-Pavlík 2016; Durdík-Juřina-Pavlík 2010; Ernée 2004; Hazlbauer 1997; Hazlbauer-Hlaváček 1997; Hazlbauer-Waldhauser 1998; Tetour 2005), ale také studie věnované typologii, motivům a ikonografii, chronologii a rekonstrukci kamnových těles (např. Hazlbauer 1998; 2000; Hazlbauer-Durdík 1996; Hazlbauer-Glosová-Volf 1996; Loskotová 2012; Motyková-Hazlbauer 1999; Pavlík-Vitanovský 2008; Soukup-Soukupová-Šrejbr 2012; Tymonová 2007; 2012; Vitanovský-Menoušková 2010; Žegklitz 2006; 2011; 2012; 2014; Žegklitz-Vitanovský-Zavřel 2009; Žegklitz-Zavřel 2004). Nově české bádání rozpoznalo význam studia dýmek v archeologickém kontextu (Musil 2008; Preusz 2015; 2016; Ulrychová 2010; Vyšohlíd 2007; 2009; 2011; 2014). Z dalších druhů artefaktů se rozbory věnovaly sklu (např. Černá 2002; Drahotová-Žegklitzová-Veselá 2003; Drobný-Sedláčková 1997; Jordánková-Sedláčková 2004; Krajíc 2003; Krajíc-Podliska-Sedláčková-Veselá 2005; Sedláčková 2000; 2001; 2001a; 2007; Sedláčková-Rohanová 2016; srov. dále sborníky Historické sklo), textiliím a obuvi (Bravermanová 1998; Bravermanová-Březinová-Hlaváček 1998; Bravermanová-Čierna 1997; Bravermanová-Kobrlová-Samohýlová 1994; 1995; Pi1ná-Schmollová 2014) nebo militariím (Beneš-Kubů-Török 1995; Chmielowiec-Kašpar-Zdaniewicz 2013; Musil 2010; 2015). Značná pozornost se v posledních letech soustředila na šperky, drobné předměty osobní výbavy a devocionálie odkryté v novověkých hrobech (Čiháčková-Omelka-Řebounová 2011; Loskotová

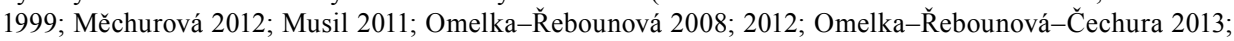

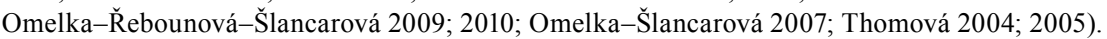

Významně se rozšírilo poznání ekofaktů a přírodního prostředí novověku, nebot' archeobiologické analýzy se již staly běžnou součástí terénních výzkumů postmedieválních lokalit. Rozrůstající se počty studií se věnují rozborům botanických makrozbytků (Beneš-Kočár 2000; Bouda-Kočár 2011; Kočár-Jankovská-Starec-Huml 2007; Kočár-Kočárová-Sůvová-Petr 2009; Kočár-Sůvová-Kočárová-Kyncl 2007; Kosňovská-Houfková-Kovář 2011; Opravil 2002; Schnederwinklová-Kostrouch-Sůvová-Kočár-Kočárová-Kyncl-Klozar-Petr 2008), nálezům koření a užitkových rostlin (Čulíková 1995; 2007; 2008; 2014; Kočár-Beneš-Preusz-Vaněček 2015; Preusz-Kodýdková-Kočár-Vaněček 2015) či rozborům archeozologických nálezů (např. Petříčková 1997; Preusz-Beneš-Kovačiková 2014; Sůvová 2008; Sůvová-Wasková 2009).

\section{Archeologie moderní doby}

Archeologie se v současnosti stále častěji zaměřuje také na témata z 19.-20. století, někdy dokonce z doby, kterou ještě pamatují někteří z nás. Archeologie moderní minulosti se v českých zemích rozvíjí 
teprve v posledních letech, ovšem je třeba zdůraznit, že archeologické památky z tohoto období byly dokumentovány a vzorkovány $\mathrm{v}$ rámci solidně prováděných terénních výzkumů ohrožených i neohrožených lokalit již dlouhá desetiletí. Zatímco rozvoj industriální archeologie - s důrazem na památky spojené s průmyslovou revolucí 19. až počátku 20. století - je u nás oproti západní Evropě a zámoří opožděn, ${ }^{3}$ formuje se archeologie naší nejmladší minulosti (někdy je označována jako archeologie současnosti - contemporary archaeology) ${ }^{4} \mathrm{v}$ minimálním časovém odstupu od mezinárodních výzkumných trendů a čeští archeologové jsou v úzkém kontaktu se zahraničními odborníky a badatelskými pracovišti. ${ }^{5}$

Archeologické lokality z moderní minulosti byly registrovány již v době, kdy se teprve formovala postmedievální archeologie, ovšem jejich cílený výzkum se začal rozvíjet až po roce 2000. V posledních letech byla realizována řada výzkumných projektů zaměřených na studium industrializace v Čechách do počátku 20. století. Jejich součástí byly terénní průzkumy a dokumentace hmotných stop různých projevů průmys-

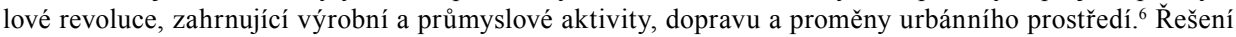
archeologických témat z moderní minulosti s využitím metod nedestruktivního výzkumu tvoří již více než jedno desetiletí součást kvalifikačních prací některých vysokoškolských archeologických pracovišt”7 a začaly se také realizovat první badatelské výzkumy využívající odkryvů menšího rozsahu. Spektrum zkoumaných témat naznačuje potenciál archeologie moderní doby. Pozornost je vedle výše zmíněného zaniklého osídlení po roce 1945 věnována novodobým hřbitovům (Farkašová-Hložek-Menšík 2013; Nenutil-RakFriedl-Funk-Hložek-Marková-Menšík-Netolický 2011; Vařeka-Vařeková 2016), pozůstatkům moderních válečných konfliktů, zejména druhé světové války, ale také studené války (Bureš 2013; Hasil-Novák-Hasil 2015; Nenutil-Rak a kol. 2011; Rak 2014; Rak-Vladař 2010), hmotnému svědectví komunistické totality (Vařeka-Vařeková 2015), letoviskům, rekreaci a volnočasovým činnostem spojeným s moderní společností (Blažková-Fialová-Matoušek 2014; Matoušek 2014; 2015b; Matoušek-Koukalová-Š́́šinková 2014; Symonds-Vařeka 2014; Šimková 2014; Vařeka-Symonds 2013); intenzivně se v posledních letech rozvíjí garbologický výzkum (Brunclíková-Sosna 2012; 2014; Sosna-Brunclíková-Henig 2013; Sosna 2016). Archeologie modernity otevírá nové perspektivy při budování teoretických modelů a může významně přispět k rozvoji archeologické teorie (v českém prostředí srov. Neustupný 2013). Archeologii chronologicky nejmladšího období byl u nás zatím věnován jediný seminář v roce 2011 pořádaný plzeňskou Katedrou archeologie, z něhož byla část příspěvků publikována ve sborníku Archeologie 19. a 20. století. Přistupy - meto$d y$ - témata (Vařeka 2013). V Čechách byla také již pořádána první mezinárodní konference archeologie modernity, zaměřená na možnosti výzkumu temného dědictví nedávné minulosti. ${ }^{8}$

\section{Závěr}

Prezentovaný přehled ukazuje postupné prosazování archeologie novověku, její zakotvení v rámci oboru na sklonku minulého století a velmi rychlý rozvoj v posledních dvou desetiletích. Výčet zkoumaných témat naznačuje dlouhodobější kontinuitu některých výzkumných oblastí, hledání nových směrů a výrazný trend rozvoje interdisciplinárních přesahů. Postmedievální archeologie v českých zemích vzešla z archeologie středověku, se kterou je nadále úzce svázána, ovšem vedle toho se na jejím formování významně podílela také etnologie, stavební historie a dějiny umění, které se studiu artefaktů z novověku přirozeně vždy věnovaly. Zároveň byla archeologie novověku úzce propojena se záchranou ohrožených památek, což otevřelo řadu možností provádět výzkumy terénních situací z nejmladší minulosti, kterým by jinak nebyla věnována pozornost, i když na druhé straně ji tato skutečnost taktéž významně ovlivnila a do jisté míry limitovala. Dosud se pouze v ojedinělých př́ípadech podařilo realizovat badatelské výzkumy řešící pomocí archeologických pramenů a metod předem položené okruhy otázek zaměřené na období novověku a moderní doby.

\footnotetext{
3 K industriální archeologii např. Buchanan 1972; Butt-Donnachie 1979; Cassela-Symonds 2005; Palmer-Nevell-Sissons 2012; PalmerNeaverson 1998.

$4 \mathrm{~V}$ českém prostředí termín archeologie současnosti použil poprvé V. Matoušek v souvislosti s výzkumem nejmladšího archeologického záznamu lidských aktivit ve skalních dutinách (Matoušek 1992).

5 Ke contemporary archeology srov. Buchli-Lucas 2001; Graves-Brown 2000; Graves-Brown-Harrison-Piccini 2013; Harrison-Schofield 2010. V současnosti je české bádání zapojeno nap̌r. do evropského projektu HERA (Humanities in European Research Area) Accessing Campscapes: Inclusive Strategies for Using European Conflicted Heritage zaměřeného na studium krajiny masového násilí a represí ve 20. století (http://www.campscapes.org/). K české archeologii moderní doby srov. Matoušek 2011; 2015; Vařeka 2013.

6 Výzkumný program realizuje Centrum pro komplexní studium materiálních a krajinotvorných aspektů industrializačního procesu na Fakultě humanitních studií UK Praha pod vedením V. Matouška (Blažková-Matoušek 2013; 2013a; srov. dále Blažková-Fialová-Matoušek 2014; Matoušek 2010; Matoušek-Blažková 2015)..

7 Výzkumy v oblasti archeologie modernity se soustřed’ují významně na Katedře archeologie Západočeské univerzity v Plzni, kde byly od roku 2001 obhájeny již čtyři desítky takto zaměřených prací ( Vařeka 2013). V posledních letech vznikly práce řešící problematiku archeologie modernity také v Archeologickém ústavu Jihočeské univerzity a objevují se i v dalších institucích. Na ZČU v Plzni je do navazujícího magisterského studia od roku 2013 zařazen specializační blok archeologie novověku a modernity

8 Konference Dark Modernities: Archaeologies of Totalitarianism, Authoritanianism and Repression pořádaná v roce 2013 v Plzni jako Annual Contemporary and Historical Archaeology in Theory Conference (CHAT).
} 
Cílený výzkum se prosazuje spíše v rámci analýz vybraných druhů nálezů ze stále se rozšiřujícího fondu pocházejícího ze záchranných výzkumů lokalit $\mathrm{z}$ tohoto období. Postmedievální archeologie se v našem prostředí dosud výrazněji nezapojila do diskusí o archeologické teorii. Přitom charakter archeologických pramenů z novověku a možnosti jejich interpretace založené na komparaci s jinými druhy historických pramenů, jejichž množství a kvalita se v průběhu nejmladší minulosti neustále rozšiřuje, nabízí jedinečné možnosti k rozvoji archeologické teorie a testování jejích postulátů. Vedle nedávno ještě plně neuznávané postmedievální archeologie se v posledních letech již profiluje nová specializace věnovaná moderní době. Ukazuje se, že archeologické prameny poskytují nenahraditelné poznatky také pro studium nedávné minulosti, nebot' archeologie je jediným oborem, který disponuje teoretickými př́stupy a metodologickými nástroji pro komplexní výzkum artefaktů, a to bez ohledu na jejich stáří. Tradičně předpokládaná značná časová vzdálenost mezi předmětem archeologického zkoumání a dneškem se tak postupně vytrácí. Domníváme se, že archeologie 16.-20. století v českých zemích by měla disponovat vlastní diskusní a konferenční platformou pravidelných badatelských setkání s minimálně středoevropským přesahem. O oprávněném místě archeologie novověku, moderní doby a současnosti mezi historickými vědami vypovídají nakonec i př́spěvky přednesené na českobudějovické konferenci v roce 2016.

Část studie byla podpořena projektem GAČR č. GA15-033805 - Proměněná země: interdisciplinární výzkum vlivu třicetileté války na venkovskou krajinu Čech.

doc. PhDr. Rudolf Krajíc, CSc., Archeologický ústav Filozofické fakulty Jihočeské univerzity v Českých Budějovicích, Na Mlýnské stoce 35, 37001 České Budějovice, Česká republika, krajic@husitskemuzeum.cz

$\dagger$ prof. PhDr. Zdeněk Měřínský, CSc., Ústav archeologie a muzeologie Filozofické fakulty Masarykovy univerzity, Arna Nováka 1, 60200 Brno, Česká republika

doc. PhDr. Pavel Vařeka, Ph.D., Katedra archeologie Filozofické fakulty Západočeské univerzity v Plzni, Sedláčkova 15, 30614 Plzeň, Česká republika,vareka@kar.zcu.cz 
